\title{
TRADE, CONFLICTS, AND POLITICAL INTEGRATION: THE REGIONAL INTERPLAYS
}

\author{
VINCENT VICARD
}

CESIFO WORKING PAPER NO. 1839

CATEgORY 7: TRAdE POLICY

NOVEMBER 2006

Presented at CESifo Venice Summer Institute, Workshop on "Understanding the LATEST WAVE Of REgIONAL TRADE AND COOPERATION AGREEMENT”, JULY 2006

An electronic version of the paper may be downloaded

- from the SSRN website: www.SSRN.com

- from the RePEc website: www.RePEc.org

- from the CESifo website: www.CESifo-group.de 


\title{
TRADE, CONFLICTS, AND POLITICAL INTEGRATION: THE REGIONAL INTERPLAYS
}

\begin{abstract}
This paper investigates the determinants of the different forms taken by regional integration in different parts of the world. This raises the issue of the relationship between economic and political integration. The theoretical model shows that, in an insecure world, the interplays between security and economic forces shape the decision to form a regional trading agreement (RTA) and its institutional design. Empirical results confirm that regionalism should be understood as a regulation mechanism: countries experiencing more interstate disputes are more likely to create a deep RTA, such as custom union or common market, whereas international insecurity deters the formation of preferential and free trade agreements.
\end{abstract}

JEL Code: D74, F02, F15, H56.

Keywords: conflict, trade, regionalism, political integration.

\author{
Vincent Vicard \\ House of Economic Sciences \\ 106 - 112 Bd de l'Hôpital \\ 75647 Paris Cédex 13 \\ France \\ vincent.vicard@malix.univ-paris1.fr
}

This draft: October 2006

First draft: June 2005

I thank Thierry Mayer for providing data and helpful suggestions. I also thank participants at the CESIFO Venice Summer Institute (2006), SMYE in Seville (2006), the EEA annual meeting in Vienna (2006) and TEAM seminar at University of Paris I Panthéon-Sorbonne (2006). 


\section{Introduction}

"We may readily conceive that a people should say, "There ought to be no war among us, for we want to make ourselves into a state; that is, we want to establish a supreme legislative, executive, and judiciary power which will reconcile our differences peaceably." But when this state says, "There ought to be no war between myself and other states, even though I acknowledge no supreme legislative power by which our rights are mutually guaranteed," it is not at all clear on what I can base my confidence in my own rights unless it is the free federation, the surrogate of the civil social order, which reason necessarily associates with the concept of the law of nations assuming that something is really meant by the latter." Immanuel Kant, Perpetual Peace: A Philosophical Sketch, 1795.

"Through the consolidation of basic production and the institution of a new High Authority, whose decisions will bind France, Germany and the other countries that join, this proposal represents the first concrete step towards a European federation, imperative for the preservation of peace." Robert Schuman, French Foreign Minister, 9 mai 1950, Paris.

The huge and increasing amount of regional trading arrangements (RTAs), - as of September 2006, 156 RTAs notified to the WTO under Enabling Close and GATT Art. XXIV were in force -, has attracted a large amount of papers, focusing in particular on their trade creating/trade diverting effects and their impact on welfare and the multilateral trade liberalization path. This body of literature generally assumes regionalism as a gradual process. As putted by Balassa (1961), RTAs can be classified from the least integrated to the more integrated, as a step by step approach to economic union, through free trade area, custom union and common market. The implicit assumption behind is that more integrated arrangements provide deeper economic integration. Empirical support for a larger effect on trade of more integrated agreements are however lacking. ${ }^{1}$ Yet a concomitant, less regarded, of the growing number of trade agreements is their increasingly different features around the world. They range from the simple exchange of preferences on a limited number of products to the elimination of almost all tariff barriers and beyond the harmonization of standards and rules on services, intellectual property rights and competition. Accordingly, the latter involves the creation of supranational institutions whose decisions bind signatory countries, like in the EU. This suggests that regional trading agreements are not homogeneous in their nature, in particular in the degree of political integration they entail. Sharing common external tariffs or the harmonization of standards or common competition policies indeed necessitate to create common institutions and to provide public goods at the regional level. On the contrary, if only a reduction of tariffs is at stake, a weak institutional framework is sufficient. This question of the form regional integration takes in different regions of the world has however barely been investigated. This relates to the relationship between economic and political integration, a criteria which seems more relevant to characterize different RTAs. RTAs should be understood as much as a process lowering barriers to trade than as a regulation institution for trade and more broadly interstate relations. ${ }^{2}$

\footnotetext{
${ }^{1}$ Most studies do not even distinguish RTAs according to their degree of integration, and investigate their effects either on a case by case basis or assuming them as homogeneous. An exception is Ghosh and Yamarik (2004b), whose results do not support any significantly larger intra-regional trade creating effect of more integrated RTAs.

${ }^{2}$ World Bank (2005) indeed shows that if one third of global trade takes place under RTAs, only half of these flows really benefits from tariff preferences (because of zero MFN rates and trade facing tariffs of $3 \%$ or less, which is not meaningful).
} 
In this respect, an important and rather ignored facet of regionalism is the insecurity issue. Historically, several regional integration processes, such as the European Union ${ }^{3}$ and Mercosur, however refer explicitly to security concerns (World Bank, 2000). The argument generally put ahead, initially developed by liberals such as Montesquieu or Kant (Barbieri, 2002), is that increasing trade ties would inhibit intra-regional military conflicts. This is especially relevant at the regional level, where countries are most concerned by both economic integration and military threats. Less emphasized, the institutional dimension of regional integration is however particularly relevant to the security issue. By favoring early settlement of conflict at supranational level (thus avoiding the politization of conflicts), institutions creating along with RTAs are likely to prevent escalation of disputes to war. Institutional frameworks greatly differ according to the depth of the RTAs created. Accordingly, their effect on international insecurity would vary. As such, it should enter the decision of countries to form a regional trading agreement and especially its features because it shapes the security externality.

The question addressed in this paper is thus twofold: how insecurity and trade interplay in RTA formation and further which countries are likely to create which kind of RTA. These questions are investigated both empirically and theoretically in a framework where trade is mutually beneficial and countries face appropriation possibilities, which can be resolved peacefully or through war. International insecurity is found to foster regional integration only to the extent that its pacifying effect exceeds the potential additional costs related to greater dyadic dependence. It suggests that economic determinants of free trade agreements emphasized by Baier and Bergstrand (2004) should be extended. Furthermore, provided that the degree of political integration embedded in RTAs shapes their pacifying effect, this result allows to handle an important open question, which is to understand why different types of RTAs are created in different regions of the world. We test empirically the theoretically derived determinants of different types of RTAs. It is found that RTAs involving a significant degree of political integration, such as custom union $(\mathrm{CU})$ or common market $(\mathrm{CM})$, are more likely to be created between countries experiencing disputes, whereas international insecurity deters free trade areas (FTA) and preferential arrangements (PA).

A large body of literature in political science has put forward that war and trade are interrelated (see Mansfield and Pollins (2004) for a survey) ${ }^{4}$. Trade interdependence has however two meanings. First, two countries are considered interdependent if it would be costly for both of them to forego their relationships, as is the case if a country cannot easily substitute its imports from a given partner. Second, a group of countries is considered interdependent if economic conditions in one are contingent on those found in the others (Mansfield and Pollins, 2004). Depending on which conception of interdependence prevails, the effect of trade on war would differ. Based on a theoretical model of conflict under asymmetric information, Martin et al. (2005) find strong empirical evidences of this ambivalent impact of trade: bilateral trade does deter war but multilateral trade dependence has the opposite effect, as it loosens bilateral interdependence. They conclude that policies affecting the geography of trade, such as RTAs, would also affect interdependence, and thus international security. Regionalism

\footnotetext{
${ }^{3}$ For instance, the preamble to the Paris Treaty of 1951 establishing the European Coal and Steel Community " resolved to substitute for age-old rivalries the merging of their essential interest; to create, by establishing an economic community, the basis for a broader and deeper community among peoples long divided by bloody conflicts."

${ }^{4}$ Their argument mostly relies on an opportunity cost analysis. Because states sharing economic linkages benefit from it, war, which is said to disrupt those linkages, is costly. Hence the prospect of higher war cost is said to deter economically interdependent states from resorting to violence to solve their disputes.
} 
however not only provide for trade preferences. It also embeds some degree of political integration and the creation of common institutions, in order to ex-ante negotiate the rules and ex-post control their implementation and application. Regional integration involve the provision of some public goods at the regional level, and possibly the creation of supranational institutions limiting sovereignty of state members. The institutional framework created and its degree of supranationalism greatly differ according to the kind of RTA, in particular because institutions are necessary as a regulation mechanism to render a given level of economic integration sustainable. Thus, creating a custom union (CU) necessitate to agree on a common external tariff and revenue distribution between state members. A common market $(\mathrm{CM})$ would necessitate more complete political institutions to agree on a broader set of issues (harmonization of regulation and standards, free movement of goods and factors,... $)^{5}$, whereas a free trade agreement (FTA) involves a weak institutional framework and a limited political integration. ${ }^{6}$ Accordingly, the depth of regional integration is defined in this paper in relation with the level of political integration.

Institutions created along the integration process are designed to manage disputes, and as such likely to favor a peaceful resolution of conflicts. ${ }^{7}$ They favor early settlement of disputes at supra-national level, with dispute settlement mechanisms for instance, but also create room for discussion and negotiation between governments or administrations (Bearce, 2003). This latter channel favors exchange of information and thus the disclosing of resolve and willingness to take risk by countries pertaining to the same RTA, thus reducing the degree of asymmetric information and limiting escalation probabilities. Regular meetings of high-level policymakers also create trust among them, which facilitate credible commitments by governments and thus act as an enforcement mechanism. These institutions reduce the degree of anarchy prevailing in interstates relationships. Thereby, only RTAs involving significant political integration, such as CU or CM, would actually manage disputes and inhibit their escalation to war, out of any trade effect ${ }^{8}$. The respective pacifying effect of political versus trade integration has nevertheless barely been assessed ${ }^{9}$. Bearce and Omori (2005) and Haftel (Forthcoming) are exceptions and suggest that economic integration per see does not reduce war probabilities, but some kinds of institutional integration do. These papers do not account for variations in interstate dispute occurrence, and do not link institutional and economic integration. Yet, the design and the scope of regional institutions are linked to the choice of different kinds of trade integration. More broadly, it relates to the question of the extent to which different RTAs offer a regulation mechanism for the

\footnotetext{
${ }^{5}$ See for instance Alesina and Wacziarg (1999) for a detailed mapping of policy areas carried out at the EU level, and Bouzas and Soltz (2000) concerning the institutional framework of MERCOSUR.

${ }^{6}$ The ASEAN free trade agreement provides an illustrative example, with weak regional institutions in order to limit any supranationalism (Best, 2005). Pomfret (1997) also emphasizes how the will to limit political integration has been incidental to the creation of NAFTA.

${ }^{7}$ This pacifying effect of political integration is related to the third leg of the "Kantian tripod": international law and organization. Together with international trade and democracy, it would lead to "perpetual peace among states".

${ }^{8}$ This argument is partly opposed to Schiff (2004), which rests on historical cases to document his hypothesis that regional wars can arise from distributional issues inside RTAs. He argues that custom unions (CU), especially between heterogeneous countries, can translate into conflicts because of an unequal distribution of gains and losses from trade policies among members or because firms agglomerate in one country, benefiting one member and hurting the other. In fact, because it implies more gains from integration and hence more distributional issues among members, Schiff (2004) assumes that a more integrated regional agreement, like CU, is more likely to lead to war. This argument follows the same line as the one developed by Grieco (1990) on the globalization / war nexus, who argues that trade liberalization creates gains whose unequal distribution may lead to conflicts.

${ }^{9}$ This question is particularly relevant in our framework because the trade creating effect of RTA is questioned by numerous studies (Ghosh and Yamarik, 2004a).
} 
intertwined international economic and political relations.

The decision to form a RTA is modeled in order to account for the interplays between security ${ }^{10}$ and trade at the regional level. The model rests on insights from both the conflict literature ${ }^{11}$ and the recent political economy literature on political (dis)integration ${ }^{12}$. The latter shows how, because large countries benefit from a market size advantage (Alesina et al., 2000) or a scale advantage in defense (Alesina and Spolaore, Forthcoming), international trade openness or international insecurity determine the number and size of countries. The model presented here is based on the framework developed in Alesina and Spolaore (2003, Chapter 8) in which security and trade issues are simultaneously introduced $^{13}$. It thus allows to differentiate between different kinds of regional integration, and to highlight their different determinants. The main features of the model are the followings. Regional integration provides a market size advantage, which is decreasing with multilateral openness. On the other side, countries experience disputes with their neighbors on some of their income, which can be resolved peacefully or through war. These models of trade and war are then embedded in a model of political integration, in which war entails the disruption of bilateral trade. By favoring trade among members, RTAs are thus found to prevent dispute escalation to war. And this pacifying effect is shaped by political institutions created along with market integration. In the end, RTA formation is endogenously determined by the degree of multilateral openness, the degree of insecurity, and heterogeneity costs associated with integration, i.e. geographic and cultural closeness. Only the more politically integrated RTAs are found to be positively associated with dispute occurrence, whereas agreements not providing enough security externalities are deterred by insecurity between two countries.

This theoretical result is tested empirically on a wide sample of countries over the 1948-2001 period, using a dataset computing 55 regional agreements and data on interstates political and military conflicts compiled by political scientists. First, using a censored probit model accounting for selection allows us to econometrically model each stage of the conflict process and disentangle the impact of each determinant on conflict initiation and escalation. We can thus confirm the idea that only deep RTAs, such as customs union and common market, inhibit dispute escalation to war out of any particular potential trade creating effect. We then turn to the final result of our theoretical model. After controlling for the endogeneity of dispute occurrence, it is found that the more integrated RTAs, such as CU and CM, are significantly more likely to be created between countries experiencing more interstate disputes. The opposite is true concerning shallow RTAs such as PA and FTA. The shadow of conflict is found to shape the institutional design of international agreements like RTAs. Rather than the actual use of military force, the very nature of the interstate system, where no supra-national institution hold the monopoly of legitimate violence, makes disputes occurrence likely to determine the form of regionalism in different regions of the world, because disputes occur under the threat of military force.

\footnotetext{
${ }^{10}$ Schiff and Winters (1997) is the only attempt to integrate security issues in RTA theory. They show that if bilateral trade provides a security externality, regionalism could maximize welfare and be a first-best equilibrium. Conflicts are however not modeled and they do not distinguish between different kind of regional integration.

${ }^{11}$ See Hirschleifer (1988) for an introduction on how conflicts can shape economic activity.

${ }^{12}$ See Ruta (2005) and Bolton et al. (1996) for a review of the literature.

${ }^{13}$ Spolaore (2004) distinguishes two different policy areas which however both take place at the national level. He thus investigates the impact of the interplays between security and economic factors on the size distribution of countries.
} 
This paper thus significantly contributes to existing literature on at least three points. First, it is the first to investigate, both theoretically and empirically, how the interplays between trade and conflicts can shape RTAs. It thus explicitly define regionalism not only as a tariffs-eliminating process but also in its regulation role. Finally, a first empirical assessment to the question of the different type of RTAs signed in different regions of the world is given.

The rest of the paper is constructed as follows. The next section presents the theoretical model of regional integration in an insecure international system. Section 3 presents data and econometric results on the effects of RTAs on war and the determinants of each kind of RTA. The last section concludes the paper.

\section{A model of regional integration in the shadow of conflict}

We consider a world where a discrete number of homogeneous countries interacts in an insecure world. Governments have to decide their foreign policy on matters of both economic/trade and security, i.e. to choose their defense capabilities and whether or not to enter a RTA, given that:

- entering a RTA means the removal of restrictions on trade with other members and thus provides productivity gains for the population, but entails heterogeneity costs;

- countries face interstate disputes over resources or production, and those are resolved either peacefully or through war;

- war disrupts trade with the opponent.

As in Alesina and Spolaore (2003, p.116), "a country is defined as an independent political unit in which (1) defense is completely and credibly centralized, (2) a unified government takes decisions over bargaining and war strategies, and (3) the net returns from conflict are distributed across its citizens"14. And a RTA is defined as a complete integration of markets, each member benefiting from a larger domestic market, i.e. an area free of barriers to trade. When entering a RTA, countries retain an independent security policy, because defense capabilities remain national.

The model is a 3-stages game: (1) countries first decide whether or not to form RTAs, (2) then they vote on their defense spending, and finally (3) uncertainty about dispute location and escalation probabilities are revealed and conflicts are resolved. This timing appears relevant because of the time frame of each stage. Forming a RTA takes time and is meant to last a long time. Building defense capabilities is also a medium term process, but is less time consuming. On the contrary, disputes occur and are resolved in the short term and it seems logical that uncertainty about conflict remains when defense and regional integration decisions are made. The model have no time dimension. Under this timing, countries thus choose whether to form RTAs or not and their level of defense spending for given heterogeneity costs, level of international insecurity, and level of multilateral openness.

Each government chooses its level of defense spending and whether or not to enter a RTA in order to maximize national utility, in an anarchic world where no supra-national institution can properly

\footnotetext{
${ }^{14}$ We thus abstract from non-unitary actor issues, and do not account for the impact of domestic politics or decision mechanism (political system) on state behavior.
} 
enforce property rights. Countries thus interact in an insecure world, and both defense spending and RTA formation are endogenous to the model. Based on conflict theory ${ }^{15}$, countries face appropriation possibilities on a part $\mathrm{R}$ of their income $\left(R<Y_{i}\right.$. For tractability reasons, the world is assumed to be divided into four similar countries, two on the Eastern continent and two on the Western continent. This world can be represented as in figure 1, each country bordering two others. International disputes occur with probability $\frac{\rho}{4}$ between each pair of bordering countries, and are resolved through bargaining or war according to the conflict game outcome. The degree of insecurity thus depends on both $\mathrm{R}$ and $\rho$.

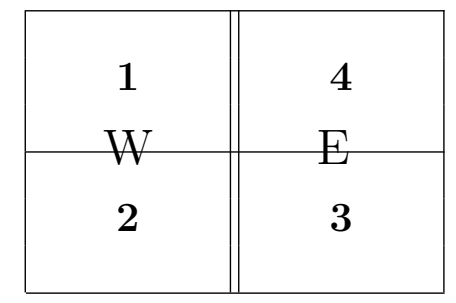

Figure 1: A 4 countries / 2 continents world

As usual in the literature on political integration, entering a RTA entails heterogeneity costs $(k)$, "due to the necessity of keeping together individuals with different interests, preferences, culture, and history" (Alesina et al., 1995). Indeed, economic integration implies common policies and the provision of some public goods at the regional level, which move away actual policies from individual ideal/preferences in each country. For simplicity, it is assumed that the costs of forming a RTA between Eastern and Western countries is prohibitive. ${ }^{16}$ Each country can therefore enter an agreement with the bordering country on the same continent. And when forming a RTA, each member bears a cost $k$. Regional integration takes place when both countries agree.

The utility function for each country i is:

$$
U_{i}=Y_{i}-\Phi_{i} k+\sum_{j \neq i} R_{i j}-d_{i} \quad \forall i, j=1,2,3,4
$$

where $Y_{i}$ is the national income $\Phi_{i}$ is a dummy variable which equals 1 if country i forms a RTA, $d_{i}$ measures defense spending $\left(0<d_{i}<Y_{i}\right)$, and $R_{i j}$ is the net return from conflict.

\section{Production, trade, and regional integration}

Alesina and Spolaore (1997) and Alesina et al. (2000) show that bigger countries benefit from a market size advantage, which decreases with global trade openness. International trade faces additional costs due to the lack of property rights protection at the interstate level. Because political and market

\footnotetext{
${ }^{15}$ See for instance Skaperdas (1992) for a complete model of production and appropriation.

${ }^{16}$ Heterogeneity costs could be considered more widely in relation with dyadic potential gains from trade creation. This assumption is thus in accordance with the natural / unnatural RTA theory (Frankel et al., 1996), which relates the desirability of RTA to the ratio of intercontinental to continental transport costs. In the same manner, multilateral liberalization exhibits a prohibitive heterogeneity cost.
} 
boundaries overlap, a big country provides public goods such as contract enforcement by local courts on a larger territory, and hence market, than small states. Citizens can thus benefit from a higher productivity. Trade liberalization nevertheless loosens the relationship between political boundaries and market size, because greater access to foreign markets renders the size of domestic market less relevant. Following this line of argumentation, regional economic integration, to the extent that it integrates national markets, would provide such big market advantage. Regionalism indeed partly dissociates market and political boundaries. In the model, creating a RTA introduces free trade among members and thus provides a big market advantage. National income is increasing with global openness and with the number of trading partners in the world. In this simple model, trade is beneficial to all countries and the first-best situation is one of complete multilateral openness. ${ }^{17}$ Country size is normalized to 1 . National income hence equals:

$$
Y_{i}=(1-\theta)\left(1+\Phi_{i}\right)+\theta s_{W}
$$

where $0<\theta<1$ is an exogenous indicator of multilateral openness $(\theta=0$ means autarky and $\theta=1$ global free trade), and $s_{W}$ is the total number of trading partners of country i in the world, including itself (it equals 4 in a peaceful world). National income is thus increasing with openness $(\theta)$ and with the number of trading partners, and the trading relationship inside RTA is comparatively more beneficial the more autarkic the world is. This definition of income illustrate the fact that in a fully globalized world, market size does not matter, but it does more the less free trade is.

In our 4 countries world, we have:

$$
Y_{i}= \begin{cases}2+2 \theta & \text { if country i belong to a RTA } \\ 1+3 \theta & \text { otherwise }\end{cases}
$$

National income is thus higher for members of a RTA than for independent countries. Those gains are decreasing with multilateral openness to trade. They equal zero in free trade and are maximum in autarky.

\section{War and peace: the conflict game}

We adopt a rationalist explanation of war. ${ }^{18}$ That is to say that war occurs because some factors make state leaders unable to ex ante reach a mutually advantageous arrangement on conflict issues. Indeed, as far as destructions are involved, the use of armed force to resolve disputes is a second best outcome and is always Pareto dominated by a negotiated settlement. The question is then to understand what precludes leaders to find and/or implement a bargaining solution. Fearon (1995) argues that only three arguments fit a rationalist definition of war: asymmetries of information on resolve or military capabilities with incentives to misrepresent them, commitment problems, and issue indivisibility. The

\footnotetext{
${ }^{17}$ Ruta (2005) shows that this simplified setting highlights the same mechanisms than a more complex, and less tractable, model of trade in intermediate goods as in Alesina et al. (2000).

${ }^{18}$ This view of war is widely developed by political scientists as well as economists. International Relations literature highlights two alternative theories. One is to explain war occurrence by irrationality of state leaders, and the second assumes that leaders may benefit from war without suffering the cost whose load rests on soldiers or citizens.
} 
model of conflict below, adapted from Alesina and Spolaore (2003, chapter 8), relies on the second argument: wars occur because state leaders are unable to credibly commit to hold their position.

Consider two countries $\mathrm{i}$ and $\mathrm{j}$ evolving in an anarchic world, i.e. where no supranational institution can enforce law. ${ }^{19}$ It is assumed that a part of their national income, $\mathrm{R}\left(0<R<Y_{i}\right)$, is potentially subject to appropriation activities. It is worth noting that any conflict issues affecting national utility could be at stake, either on resource, rent sharing, ideology... A dispute may be settled peacefully through bargaining or through war. If both countries bargain, the status quo holds and each retains $\mathrm{R}$, its share of the pooled income subject to appropriation. ${ }^{20}$ Otherwise, the distribution of payoffs depends on the relative military strength of opponents and each country undergoes war costs. Players face perfect information in the model. A traditional ratio contest success function defines how the valuable pie $2 \mathrm{R}$ is distributed in case of military fight (Hirschleifer, 1988). When both countries choose the fighting strategy, payoffs are the followings:

$$
\begin{aligned}
& R_{f f}^{i}=2 R \frac{d_{i}}{d_{i}+d_{j}}-C_{i j} \\
& R_{f f}^{j}=2 R \frac{d_{j}}{d_{i}+d_{j}}-C_{i j}
\end{aligned}
$$

where $d_{i}\left(d_{j}\right)$ is country i's (j's) military spending. ${ }^{21}$

As far as war is costly, the war outcome is always Pareto dominated by the bargaining outcome. In absence of any other specification, the dominant strategy is (bargain, bargain). But as Grossman (2004) outlines, a peaceful negotiated settlement is credible only if none has incentives to deviate, which is to say that each opponent is left better off with the status quo than if he starts a war. In this respect, if a military advantage of attacking exists, and if that advantage exceeds the cost of war, none can credibly commit not to deviate. This first striker advantage, denoted E, could materialize through a higher probability of winning or smaller war damages, etc. Its width is determined by factors such as military technology or geography. It is assumed that $\mathrm{E}$ is the same for all countries and that the country choosing to bargain when its opponent attacks undergoes a mirroring cost of equal magnitude. Strategy sets and outcomes are summarized in table 1.

So in a situation where the first striker advantage is sufficiently large, i.e. if $E>C_{i j}$, the Paretooptimal strategy, where both countries choose to bargain, is not a Nash-equilibrium. Given the opponent strategy, a country has incentives to deviate and strike first. ${ }^{22}$ In this case, it is straightforward to

\footnotetext{
${ }^{19}$ International relations theory introduces the anarchical nature of the international system in contrast with national politics where the government is said to have the monopoly on legal coercion and armed force, and can thus enforce law and impose peaceful dispute settlements.

${ }^{20}$ Without loss of generality and in order to avoid imposing constraints on the negotiation protocol, we consider that countries retain preexisting rights on resources subject to appropriation, such that the status quo holds if countries bargain. It is thus assumed that the status quo is inside a restricted interval of bargaining interval. This restriction just assures that war arise because of commitment problems, and not issue indivisibility.

${ }^{21} \frac{d_{i}}{d_{i}+d_{j}}$ can be understood either as the probability of victory or as the proportion of the pie country i won in the event of war, when states are risk neutral. The former interpretation is privileged here.

${ }^{22}$ The preexisting rights constraint is then: $E-C_{i j}>R\left(1-\frac{2 d_{i}}{d_{i}+d_{j}}\right)>-E-C_{i j}$ if $d_{i} \neq d_{j}$. When $d_{i}=d_{j}$, no constraint has to be fulfilled.
} 
Table 1: Conflict game outcomes

\begin{tabular}{|c|c|c|}
\hline & & \\
\hline & Bargain & Fight \\
\hline Bargain & $(R ; R)$ & $\begin{array}{l}\left(2 R \frac{d_{i}}{d_{i}+d_{j}}-C_{i j}-E\right. \\
\left.\quad 2 R \frac{d_{j}}{d_{i}+d_{j}}-C_{i j}+E\right)\end{array}$ \\
\hline Fight & $\begin{array}{r}\left(2 R \frac{d_{i}}{d_{i}+d_{j}}-C_{i j}+E\right. \\
\left.\quad 2 R \frac{d_{j}}{d_{i}+d_{j}}-C_{i j}-E\right)\end{array}$ & $\begin{array}{l}\left(2 R \frac{d_{i}}{d_{i}+d_{j}}-C_{i j}\right. \\
\left.\quad 2 R \frac{d_{j}}{d_{i}+d_{j}}-C_{i j}\right)\end{array}$ \\
\hline
\end{tabular}

show that the only Nash equilibrium is (fight,fight). ${ }^{23}$ Otherwise, both (bargain, bargain) and (fight, fight) profiles are Nash equilibriums. But using refinements introduced by Bernheim et al. (1987) on coalition of players, a unique coalition-proof Nash equilibrium emerges in each situation: depending on $E$ relative to $C_{i j}$, a unique coalition-proof Nash-equilibrium exists; the strategy profile outcome is (bargain, bargain) if $E<C_{i j}$, and (fight, fight) if $E>C_{i j}$. From this result, a probability of dispute escalation to war can be derived. If the probability that $E>C_{i j}$ is noted $\pi$, a dispute ends up in war with probability $\pi$ and is settled peacefully with probability $1-\pi$.

A country has a probability $\frac{\rho}{4}$ to experience a dispute with each of its two neighbors. Once a dispute emerges, it is resolved according to our model of conflict above. Expected net returns from conflict between two countries $\mathrm{i}$ and $\mathrm{j}$ depend on the probability of dispute $\rho$ and the probability of conflict escalation to war $\pi$ as follows:

$$
R_{i j}=\frac{\rho \pi}{4}\left[2 R \frac{d_{i}}{d_{i}+d_{j}}-C_{i j}-R\right]
$$

\section{Trade, conflict and regional integration}

In line with empirical evidence of a large and persistent effect of war on bilateral trade, provided by Martin et al. (2005) and Glick and Taylor (2005), war is assumed to disrupt trade with opponent. The cost underwent by countries entering a war is entirely related to bilateral trade disruption. ${ }^{24}$ War cost thus equals income at peace less income at war: $C_{i j}=Y_{i}^{\text {peace }}-Y_{i}^{\text {war }}$.

\footnotetext{
${ }^{23}$ If the attacking advantage is high enough, no country will choose to bargain, because it would be better off with open warfare than with a surprise attack.

${ }^{24}$ For simplicity, and without loss of generality, direct war costs and potential effects of war on multilateral trade, which are found to be smaller but significant, are ignored.
} 
From equation 2, it follows:

$$
C_{i j}= \begin{cases}1 & \text { if countries } \mathrm{i} \text { and } \mathrm{j} \text { belong to the same RTA } \\ \theta & \text { otherwise }\end{cases}
$$

The opportunity cost of war is larger, the higher the gains from the bilateral trading relationship. Together with the conflict game, this result has two corollaries. First, conflict escalation to war is less likely among countries trading intensively with each other. $\pi$ is thus a decreasing function of $\theta$ : $\pi_{\theta}^{\prime}<0$ and $0<\pi<1$. Second, the probability of conflict escalation to war is smaller among countries pertaining to the same RTA, because they trade more with each other, which raises the opportunity cost from war and deters conflict escalation. We have: $0<\pi^{R T A}<\pi<1$.

The form of the $\pi$ function and the difference between $\pi$ and $\pi^{R T A}$ is a function of E, the attacking advantage, which in turn depend on military technology and geography (supposed fixed in the short term), and the level of multilateral trade openness $\theta$. Notwithstanding, no particular form is imposed to $\pi$ function, which is likely to depend on how specific RTAs affect the geography of trade and on institutional design of each arrangement. ${ }^{25}$

Equilibrium defense spending can now be derived. They maximize each country's expected net return from conflict. Equilibrium defense spending depends on RTA membership as follows:

$$
d_{i}= \begin{cases}\frac{R \rho \pi}{4} & \text { if country i belong to a RTA } \\ \frac{R \rho\left(\pi+\pi^{R T A}\right)}{8} & \text { else }\end{cases}
$$

Proof in appendix A.

Defense spending are thus reduced in a world with RTAs. It is worth noting that defense spending are pure waste in this model with appropriation possibilities. All countries would be better off if none diverts resources in defense capabilities building.

This result is in accordance with empirical evidence on the significance of neighborhood in explaining the level of military spending. Collier and Hoeffler (2005) indeed find that the huge difference in military spending across countries, which range from close to zero to $45 \%$ of GDP, is strongly influenced by neighbors, because of arms race behavior. They estimate that the decision by one country to raise its military spending can result in a three times more important increase for each country in the region.

From equation 6, 7 and 8, the net expected gain from conflict can be computed. It equals, for all countries $\mathrm{j}$ bordering country $\mathrm{i}$ :

$$
R_{i}=\sum_{j \neq i} R_{i j}= \begin{cases}\frac{-\rho}{4}\left[\pi \theta+\pi^{R T A}\right] & \text { if country i belong to a RTA } \\ \frac{-\rho}{2} \pi \theta & \text { else }\end{cases}
$$

\footnotetext{
${ }^{25}$ This question of the respective impact of political Vs trade integration on war occurrence is largely an empirical matter, on which we do not want to impose any theoretical a priori. This question will be handled in the first part of the empirical section.
} 
And the "conflict related" gains from regional integration are:

$$
R_{i}^{R T A}-R_{i}=\frac{\rho}{4}\left(\pi \theta-\pi^{R T A}\right)
$$

The right hand side balances expected war costs in each configuration of the world. Its sign depends on the tradeoff between expected costs from conflict inside and outside the RTA. In fact if the inhibiting effect of regional integration on conflict escalation exceeds the higher opportunity cost of war, "conflict related" gains are positive.

Interestingly, if $\pi_{\theta}^{\prime}>\frac{-\pi}{\theta}$, security gains from integration are increasing in $\theta$. In this case, globalization has two opposite effects with respect to regional integration: the large market advantage decreases with trade liberalization whereas the associated security gains increase.

\section{Equilibria}

Conditions under which regional integration will take place can now be derived from equation 1, 3, 8 and 10. Country i will prefer regional integration to economic independence if and only if

$$
\frac{\rho}{8}\left[\pi(2 \theta+R)-\pi^{R T A}(2+R)\right]+1-\theta>k
$$

Proof in appendix A.

This inequation balances expected benefits from regional integration to its cost, for given heterogeneity costs, level of multilateral openness, and level of international security. Incentives to integrate depends positively on the amount of income subject to conflict, and negatively on global trade openness and heterogeneity cost of integration. Furthermore, international insecurity $(\rho)$ has an ambiguous effect on incentives to integrate. From equation 11, the following testable proposition can be derived.

Testable proposition: International insecurity favors the creation of RTAs providing a significant security externality, whereas it deters the formation of other RTAs.

This result will be explored empirically in the next section. In fact, incentives to form a RTA depend on the difference between $\pi$ and $\pi^{R T A}$, i.e. on the way regional integration translates into inhibiting mechanism. If the pacifying effect of regional integration more than compensates the larger war costs (i.e. the difference between $\pi$ and $\pi_{R T A}$ is sufficiently large), then the occurrence of international disputes favors the creation of RTAs. The opposite is true if the pacifying effect of regional integration is not sufficiently large. In our model, the form of the $\pi$ function determines this difference. Provided that political institutions designed to foster trade affect war occurrence, it seems straightforward to suppose that the form of this function depends on institutions created along the integration process as well as how it affects the geography of trade. Indeed, the integration of markets needs supranational political institutions to be sustainable and involves the provision of public goods in common. The more integrated the RTA is, the more political institutions are needed to implement the agreement. And this degree of political integration needed for a given level of economic integration to be sustainable shapes the way intra-regional conflicts are managed, that is the peaceful impact of integration. 
It is worth noting that the probability that an international war actually occurs is endogenous to the model, as it depends on the configuration of the world. Let $\Omega$ be this probability, by definition:

$$
\Omega=\frac{\rho}{2}\left[\phi \pi^{R T A}+(2-\phi) \pi\right]
$$

Any factor affecting decisions on regional integration will thus indirectly affect the probability of observing a war. A reduction of international insecurity ( $\rho$ decreases), could, for instance, by reducing incentives to integrate, raises war occurrence. A less insecure world, i.e. a $\rho^{\prime}$ such that $\rho^{\prime}<\rho$, could result in a higher probability to observe an actual war, $\Omega_{\rho^{\prime}}>\Omega_{\rho}$.

\section{Extension: size asymmetry}

So, the analysis has been restricted to the symmetric case. This section extends the model to the case of a world with asymmetric countries, where one western country is assumed to be larger. Its size equals $s_{k}=1+3 \sigma$, whereas other country size equals $s_{h}=1-\sigma$. As previously, world size remains equal to four. Hence, income is defined by:

$$
Y_{i}=(1-\theta)\left(s_{i}+\phi_{i j} s_{j}\right)+\theta s_{W}
$$

So

$$
Y_{i}= \begin{cases}1-\sigma+(3+\sigma) \theta & \text { if there is no RTA and } i \neq k \\ 1-\sigma+(3+\sigma) \theta & \text { if there is no RTA and } \mathrm{i}=\mathrm{k} \\ 2-2 \sigma+(2+2 \sigma) \theta & \text { if country i belongs to a RTA with } \mathrm{j} \text { and } j \neq k \\ 2+2 \sigma+(2-2 \sigma) \theta & \text { if country i belongs to a RTA with } \mathrm{j} \text { and } \mathrm{j}=\mathrm{k} \\ 2+2 \sigma+(2-2 \sigma) \theta & \text { if country i=k belongs to a RTA }\end{cases}
$$

War costs are thus as follows:

$$
C_{i j}= \begin{cases}(1-\sigma) \theta & \text { if there is no RTA and } j \neq k \\ (1+3 \sigma) \theta & \text { if there is no RTA and } j=k \\ 1-\sigma & \text { if } \mathrm{i} \text { and } \mathrm{j} \text { belong to the same RTA and } j \neq k \\ 1+3 \sigma & \text { if } \mathrm{i} \text { and } \mathrm{j} \text { belong to the same RTA and } j=k\end{cases}
$$

War probabilities depend on the least constrained state, i.e. the country in the dyad whose war cost is smaller. It is the large country in dyads to which it belongs. As previously, we thus have $\pi>\pi_{R T A}$ on each continent.

Hence, as above, equilibrium defense spending equals in all countries:

$$
d_{i}= \begin{cases}\frac{R \rho \pi}{4} & \text { if country i belongs to a RTA } \\ \frac{R \rho\left(\pi+\pi^{R T A}\right)}{8} & \text { else }\end{cases}
$$

Proof in appendix A. 
Interestingly, the result of Alesina and Spolaore (Forthcoming), that large countries benefit from a scale advantage in conflict, holds in this model. Indeed, defense spending in percentage of income are smaller in the large country than in the small countries.

So for given heterogeneity costs, level of multilateral openness, and level of international security, regional integration will take place if and only if, for any country i:

$$
\frac{\rho}{8}\left[\pi^{R T A}(2-2 \sigma+R)-\pi(2 \theta-2 \sigma \theta+R)\right]+(1-\theta)(1-\sigma)>k
$$

Proof in appendix A.

Incentives to integrate are thus decreasing the more unequal the world size distribution is. That is to say that regional integration is more likely the larger the economic size of partner countries with respect to the rest of the world, and the less unequal the economic size inside RTA is. In addition, it is worth noting that this deterrent size effect decreases with multilateral openness. 


\section{Econometrics}

In this section, the final result of the theoretical model is empirically tested, and especially the testable proposition derived from equation 11. It suggests that determinants of regional integration differ according to the kind of RTA created. More integrated RTAs, i.e. those providing significant security externalities, are more likely among countries experiencing lots of interstate disputes, whereas the opposite is true for other RTAs. However, it is first necessary to assess formally which kinds of RTAs provide security externality.

\section{The effect of regionalism on war}

The preliminary step of this empirical analysis is to investigate the pacifying effect of different kind of RTAs on interstates relations. As explicitly modeled in the theoretical model, war results from a two-stage process, namely conflict initiation and conflict escalation to war. A war cannot occur unless a dispute arises beforehand. Using a simple probit model to estimate the conditional probability of war ( $\pi$ in the theoretical model) could thus yield results subject to a selection bias. The probability of existence of a dispute $(\rho)$ between two given countries should be taken into account. Once a conflict emerges, it is likely that the process driving its evolution greatly differs from the one explaining its initiation. Different factors could therefore have different impacts depending on the stage of the conflict process. For instance, neighboring countries are likely to face more disputes and also to be more prone to escalate them to war, because sharing a common border makes the use of armed force easier. Using a wide definition of conflicts, including diplomatic and economic disputes, Kinsella and Russett (2002) show that determinants of conflict onset and escalation differ and that the effect of some of them are nonmonotonic on the whole range of the conflict process. They find power parity and major power status to foster only dispute initiation, whereas alliances foster it but deter conflict escalation.

Moreover selection effects have to be modeled because the escalation process is observed only if a dispute occurred. Unobserved variables, such as commitment, resolve or willingness to take risk, could therefore affect differently escalation and initiation process, or could be disclosed at different stage of the conflict process. As Fearon (1995) emphasizes, asymmetries of information are particularly relevant for explaining war occurrence. States enters disputes with few information on opponent's commitment or resolve. But this information is disclosed along the conflict process and could therefore influence later stages. Boehmer et al. (2001) argue that states use low level conflicts to signal their resolve in a dispute. This way, they substitute diplomatic or economic hostility for military conflicts. The degree of asymmetric information therefore differs according to the stage of the conflict process. And information disclosed when a dispute is initiated is likely to influence its escalation process. ${ }^{26}$ Escalation process is estimated for each dyad-year using a censored probit accounting for selection. ${ }^{27}$ It allows to jointly model conflict initiation and escalation and to account for the impact of each factor on different stages of the conflict process. Two equations are thus jointly estimated, one explaining

\footnotetext{
${ }^{26}$ Econometrically speaking, error terms of conflict initiation and escalation equations could be correlated, which creates room for selection bias. The selection effect could be positive or negative, depending on how unobserved factors, like commitment or resolve, affect both the likelihood of dispute initiation and the settlement of conflict.

${ }^{27}$ The likelihood function is derived from a bivariate probit and accounts for selection. See Reed (2000) for a discussion of alternative econometric models.
} 
the dispute initiation and the second the conflict escalation to war. Consider $y_{1}$ and $y_{2}$, two latent (unobserved ) variables, representing the difference in utility levels from dispute initiation and dispute escalation to war respectively. The model estimated is derived from a standard bivariate probit model:

$$
\begin{aligned}
& y_{1}=\beta_{1} X_{1}+\epsilon_{1} \quad \text { and dispute }=\left\{\begin{array}{l}
1 \text { if } y_{1}>0 \\
0 \text { if } y_{1} \leq 0
\end{array}\right. \\
& y_{2}=\beta_{2} X_{2}+\epsilon_{2} \quad \text { and } w a r=\left\{\begin{array}{l}
1 \text { if } y_{2}>0 \\
0 \text { if } y_{2} \leq 0
\end{array}\right.
\end{aligned}
$$

where $X_{1,2}$ are vectors of explanatory variables, $\beta_{1,2}$ vectors of parameters, and errors terms $\epsilon_{1}$ and $\epsilon_{2}$ are assumed to be independent from $X_{1,2}$ and to follow $E\left(\epsilon_{1}\right)=E\left(\epsilon_{2}\right)=0, \operatorname{Var}\left(\epsilon_{1}\right)=\operatorname{Var}\left(\epsilon_{2}\right)=1$, and $\operatorname{Cov}\left[\epsilon_{1}, \epsilon_{2}\right]=\varrho$. The action to escalate a dispute to war can however not be observed unless a dispute occurs. Hence, the log-likelihood function is based on unconditional probabilities associated with the three possible outcomes (Greene, 2003, p.713): no dispute (dispute $=0$ ), a dispute emerges but does not escalate to war (dispute $=1$ and war $=0)$, and the dispute escalates into war (dispute $=1$ and $w a r=1)$.

\subsection{Data}

What we are interested in in this paper is the degree of political integration implied by each type of trading agreement. Therefore we do not consider their relative ability to foster trade among members countries but the actual negotiation and implementation of trading arrangements. RTA whose dispositions have never been really implemented are thus excluded. The data set collects all regional (i.e. three or more parties) trade arrangements which take the form of Preferential Trading Arrangement (PA), Free Trade Area (FTA), Customs Union (CU), Common market (CM), or Political Agreement $(\mathrm{PoA})^{28}$, in force at least a certain period of time between 1948 and 2001. Bilateral arrangements as well as non reciprocal arrangements are thus excluded from our study. ${ }^{29}$ This restriction is imposed for at least two reasons: the institutional framework of bilateral trading arrangements is limited and likely to differ from regional arrangements, and it is difficult to compute all bilateral arrangements and especially their depth on a long time span as ours. ${ }^{30}$ The definition of RTAs adopted here is thus close to what Ethier (1998) calls geographical regionalism. Information on trading agreements have been assembled from notifications to the $\mathrm{WTO}^{31}$, Foroutan $(1993,1998)$, Langhammer and Hiemenz (1990), Frankel (1997), Machlup (1977) and other public sources. Unless otherwise mentioned in our sources, an agreement is assumed to be "in force" at the date defined in the treaty and, if not available, once the agreement has been signed and ratified. It should, however, be noted that this does

\footnotetext{
${ }^{28}$ Based on WTO, a PA is defined as agreements among three or more parties in which reciprocal preferences are exchanged to cover a limited range of the parties' trade in goods (partial in scope); a FTA is defined as agreements among three or more parties in which reciprocal preferences are exchanged to cover a large spectrum of the parties' trade in goods; a CU is defined as a RTA with a common external tariff in addition to the exchange of trade preferences; a $\mathrm{CM}$ is defined as a RTA allowing free movements of factors (goods, capital and workers); and a PoA is defined as an organizations aiming at liberalizing trade among its members but falling short of providing for tariff preferences inherent in a CU, FTA or PA.

${ }^{29}$ Exceptions are the inclusion of CU between EU and Malta, Cyprus and Turkey, and CU between Slovakia and Czech Republic, and the Closer Economic Relations agreement between Australia and New-Zealand.

${ }^{30}$ Moreover, contrary to RTAs, bilateral arrangements are signed between distant countries, less likely to experience any interstates conflicts, and are thus less relevant in our purpose. We shall return to this in the final section.

${ }^{31} \mathrm{http}$ ://www.wto.org/english/tratop_e/region_e/region_e.htm
} 
not necessarily mean that all provisions of the agreement have been fully implemented. Four dummy variables are defined and coded 1 if both country in the dyad are members of the same RTA during the year considered: PoA, PA, FTA and deep RTA, which aggregates CM and CU. Deep RTAs are those involving a more complete political integration and the provision of some public goods in common. Our data set reports 55 RTA over the period 1948-2001, of which 8 are coded as PoA, 17 PA, 12 FTA, $16 \mathrm{CU}$ and $3 \mathrm{CM}$ (see Appendix B1 for a detailed list).

The main dependent variable is the occurrence of a Military Interstate Disputes (MID) between two states in a given year. This variable is coded from the COW database (Bremer et al., 1996) and accounts for all interstates disputes on the 1948-2001 period involving the display or the use of armed force, i.e. a MID of hostility level 3 (display of force), 4 (use of force) or 5 (war) in the COW ${ }^{32}$. Qualitative data provided by armed conflicts data sets, such as MID used as our explained variable, implies that actors, duration, geographical location and intensity of each conflict have been defined by researchers. Thus, only rare events such as war can be considered. But to assess dispute initiation process, we need to measure conflicts of lower intensity, not reported in such data sets. An alternative type of database is available: event data which account for a broader range of interstates relations. Event data are reported, by trained students or automatically by computers, on a day by day basis from newspapers or wire services and coded by actor, target, as well as action form and date. In comparison to armed conflict data sets, it is quasi impossible to know whether different events pertain to the same united historical case. If assessing the evolution of a given conflict is hardly feasible, such data enable to measure the occurrence of a dispute a given year, which is what we are interested in in the present analysis. Knowing if a conflict lasts and how it evolves is indeed not the question addressed here. Our aim is to assess, when a dispute occurs, whether it is settled peacefully or ends up in war. In addition, data on daily events have the great advantage of providing information whatever the intensity of the underlying event. It is thus feasible to measure conflicts at different level of intensity. Events data compiled by Kinsella and Russett (2002) and available on their website ${ }^{33}$ are used to measure the occurrence of a dispute exceeding a certain threshold defined as strong verbal hostility. ${ }^{34}$ They overlap data from three event databases, the Conflict and Peace Data Bank (COPDAB), the World Event/Interaction Survey (WEIS) and the Protocol for the Assessment of Nonviolent Direct Action (PANDA), to construct a dummy variable coded 1 if a dispute occurs for any dyad-year over the 1950-1992 period. ${ }^{35}$ Table 2 provides event categories coded as disputes and their equivalent on the widely used Goldstein (1992) scale, which rates events between -10 and +10 according to the level of conflict or cooperation they embed. Only events classified at least as conflictual as categories "Cancel or postpone planned events" and "Charge; criticize; blame; disapprove" are coded as a dispute. Out

\footnotetext{
${ }^{32}$ War is restrictively defined as a MID involving at least 1000 deaths of military personnel. Most studies of war use a wider definition of military conflicts as we do, which do not include the MID level 2 (threat to use force). More information is available from COW website: http://cow2.la.psu.edu/.

${ }^{33} \mathrm{http}$ ://www . yale .edu/unsy/democ/democ1.htm

${ }^{34}$ See Kinsella and Russett (2002, p.1054-1055) for more details on databases used and the operationalizing of the minimum conflict intensity threshold. Schrodt and Gerner (2000) present the limitations related to the use of events data. Thanks to the use of events exceeding a certain intensity in our analysis, much of the biases they identify are limited.

${ }^{35} 196$ cases exhibit a MID but no dispute. We follow Kinsella and Russett (2002) and treat them as measurement errors, due to the fact that events data sets rely on major news media and do not cover accordingly all regions of the world. The dummy variable is thus recoded as if a dispute occurred.
} 
of the 201627 dyad-years for which such event data are available in our basic specification, 12047 experience a dispute, of which 1007 escalate into MID.

Table 2: Events and Goldstein scale

\begin{tabular}{lc}
\hline \hline Event category & Goldstein \\
\hline Request action; call for & $-0,1$ \\
Explicit decline to comment & $-0,1$ \\
Urge or suggest action or policy & $-0,1$ \\
Comment on situation & $-0,2$ \\
Deny an accusation & $-0,9$ \\
Deny an attributed policy, action, role or position & $-1,1$ \\
Grant asylum & $-1,1$ \\
Make complaint (not formal) & $-1,9$ \\
\hline Cancel or postpone planned events & $-2,2$ \\
Charge; criticize; blame; disapprove & $-2,2$ \\
Issue formal complaint or protest & $-2,4$ \\
Give warning & -3 \\
Denounce; denigrate; abuse & $-3,4$ \\
Halt negotiation & $-3,8$ \\
Turn down proposal; reject protest, demand, threat & -4 \\
Refuse; oppose; refuse to allow & $-4,1$ \\
Reduce routine international activity; recall officials & $-4,1$ \\
Detain or arrest person(s) & $-4,4$ \\
Threat without specific negative sanction stated & $-4,4$ \\
Issue order or command, insist, demand compliance & $-4,9$ \\
Expel organization or group & $-4,9$ \\
Order person or personnel out of country & -5 \\
Nonmilitary demonstration, walk out on & $-5,2$ \\
Reduce or cut off aid or assistance; act to punish/deprive & $-5,6$ \\
Threat with specific negative nonmilitary sanction & $-5,8$ \\
Ultimatum; threat with negative sanction and time limit & $-6,9$ \\
Threat with force specified & -7 \\
Break diplomatic relations & -7 \\
Armed force mobilization, exercise, display; military buildup & $-7,6$ \\
Noninjury destructive action & $-8,3$ \\
Nonmilitary destruction/injury & $-8,7$ \\
Seize position or possessions & $-9,2$ \\
Military attack; clash; assault & -10 \\
\hline \hline
\end{tabular}

Source: Goldstein (1992)

Trade data are from the database assembled by Katherine Barbieri ${ }^{36}$, who uses mostly information from the IMF and the League of Nations international trade statistics. Her data spans over the 1870-1992 period. It is completed by Martin et al. (2005) up to 2001 using the IMF DOTS database. Income data also comes from Martin et al. (2005), and are assembled from Katherine Barbieri and the World Bank WDI database.

Others control variables are described below. Geographic data are from CEPII ${ }^{37}$, and military data are from the COW project. The composite democracy indicator is taken from Polity IV ${ }^{38}$. It measures openness/closedness of political institutions on a $-10 /+10$ scale (10 means high democracy). Finally, UN vote correlation is taken from "The Affinity of Nations: Similarity of State Voting Positions in the UN General Assembly" computed by Erik Gartzke ${ }^{39}$.

\footnotetext{
${ }^{36}$ See http://sitemason.vanderbilt.edu/site/k5vj7G/new_page_builder_4

${ }^{37}$ http://www.cepii.fr/francgraph/bdd/distances.htm

${ }^{38}$ http : //www. cidcm. umd.edu/inscr/polity/

${ }^{39}$ http : //www. columbia. edu/ eg589/
} 


\section{$1.2 \quad$ Econometric results}

Results are presented in table 3. Estimates of the selection effect are found to be negative. Their significance nevertheless decreases with the number of control included, and it turns insignificant in specification (4) and (5). The selection effect of unobserved variables vanishes when enough dyadic specific control are added, and particularly proxy for cultural and political proximity such as vote correlation at the UN general assembly and dummy for country pairs ever in a colonial relationship and for countries sharing a common colonizer. The issue of nonmonotony of the impact of determinants of war appears more relevant, since several determinants have opposed effects on conflict initiation and escalation.

Specification (1) displays the basic model. It includes the 4 variables of RTA membership and two basic determinants of war: the number of peaceful years between the two countries in the dyad to account for time dependency, which is common in this literature, and the log of the distance between the main cities of the two countries, as a proxy of the opportunity of armed conflicts. More integrated RTAs are however also those likely to increase the more intra-regional trade. In order to disentangle pacifying effect of regionalism going through the trade channel or through the political integration channel, trade interdependence should be controlled for. The choice of trade variables follows Martin et al. (2005), which is the more theoretically grounded and comprehensive paper on the relationship between trade and war. Their argument is that bilateral trade deters conflict escalation to war whereas multilateral trade openness fosters war occurrence. Hence, both a proxy for bilateral trade interdependence (the log of the mean of bilateral trade flows in percentage of GDP), and another for multilateral trade dependence (the log of the mean of multilateral (excluding bilateral) imports in percentage of GDP) are included, as well as a dummy for dyad experiencing zero trade flows (both exports and imports). ${ }^{40}$ Martin et al. (2005) also add interaction variables between distance and their two variables of interest, which are deemed to account for the dyadic difference in dispute occurrence, that they do not explicitly measure. The methodology adopted here does, so these interaction terms are ignored in the estimation of the escalation process. In order to remove the potential contemporaneous effect of war on bilateral and multilateral trade, trade variables are lagged 5 years. Martin et al. (2005) indeed show that a 5-years lag is enough to remove any contemporaneous reverse effect of war on trade. ${ }^{41}$ As expected, among our variables of interest, only deep RTA membership exhibits a significant and negative coefficient at the escalation stage of the conflict process. FTA membership do reduce dispute initiation, whereas PoA membership increases the number of dispute. Concerning trade, results presented here tend to confirm its ambiguous effect on war, but the mechanism appears slightly different. Bilateral trade does reduce escalation to war probabilities, as well as the number of dispute, but multilateral openness fosters dispute initiation. By raising domestic economy dependency on external trade, openness would render country more sensitive to foreign decisions and increases dispute occurrence.

\footnotetext{
${ }^{40}$ These are not missing values but country pairs for which no trade is reported. Martin et al. (2005) interpret this variable as a control for trade fixed costs.

${ }^{41}$ RTA membership is obviously not affected by any contemporaneous effect of military conflict, because it takes time to negotiate and implement an agreement. Using panel fixed effect or instrumental variable econometric models to control for endogeneity potentially arising from omitted variables likely to affect simultaneously war and RTA membership, as Martin et al. (2005) do concerning war and trade, is not possible here because too few dyads enter both war and RTA over our time period and exogenous determinants of RTA membership are not available.
} 
Other control variables have the expected sign: the number of peaceful years in the dyad reduces the probability of war escalation as well as the number of disputes, and distance reduces the probability of escalation to war. Surprisingly, more distant countries seem to experience more disputes, which we attribute to a problem of multicollinearity due to the inclusion of interaction variables. ${ }^{42}$ This confirms our theoretical finding that the deeper RTAs, i.e. those implying political integration, are those exerting a pacifying effect, out of any trade effect.

Specification (2) includes a control variable for countries sharing a common border, which is likely to affect war occurrence, trade relations and RTA membership. As expected, contiguity increases both the number of disputes and the probability of escalation to war. Results remain similar, except that the coefficient on distance becomes insignificant. In specification (3), a proxy for the democratic status of states in the dyad is added. More democratic countries are indeed likely to be at the same time less prone to escalate conflicts into war, and more prone to form a RTA. Its omission could biased the coefficient on RTA membership upward. Then, in specification (4) controls for cultural, historical and diplomatic affinities between countries are included. These are the UN general assembly vote correlation, a dummy for pairs ever in a colonial relationship and another for countries sharing a common colonizer. Countries sharing affinities are more likely to be part of the same RTA, to trade more and to be less warlike, whereas countries sharing common colonial history would exhibit more unresolved conflict issues. As expected, more democratic countries are less likely to escalate a dispute into war, but they experience more disputes. Sharing political affinities significantly reduce disputes between states, but has no effect on escalation to war probabilities. On the other hand, countries sharing colonial linkage face significantly more disputes. Finally, controls for country size , - a bigger territory is more difficult to defend and is exposed to more opponents, but a big country is also less open to trade and is particular with respect to regional integration, as it often implies asymmetric integration -, and countries sharing a common defense alliance are included in specification (5). Big countries in fact initiate significantly more disputes, but no effect is recorded on the escalation stage. Sharing an alliance appears to have an ambiguous effect on war occurrence, as it reduces escalation probabilities but fosters dispute initiation.

Concerning RTA membership variables, only deep RTA membership has a significant effect on conflict escalation along all alternative estimations. Its coefficient on probabilities of escalation to war is, as expected, negative and significant, at the $5 \%$ level in the more complete specification (5). Deep RTAs thus reduce probabilities of war, by preventing disputes to escalate into war. This effect is however slightly counterbalanced by the fact that countries pertaining to such agreements initiate significantly more disputes. This result is in line with the argument that countries use conflicts as an instrument in international relations, and substitute lower level conflicts to armed conflicts (Boehmer et al., 2001). On the contrary, FTA and PA membership are found to have no significant effect on war. Finally, PoA yield a positive and significant coefficient concerning dispute initiation. An explanation would be that countries facing lots of disputes, propensity that we do not control for, select into forming a PoA. The results of this section clearly confirm the hypothesis that only the political integration involved by deep RTAs provides security externalities. These kind of agreements (CU and CM) are

\footnotetext{
${ }^{42}$ Without these interaction terms, distance is found to significantly reduce dispute occurrence, and its effect on escalation probabilities remains negative but insignificant. Their omission renders coefficients on trade variables particularly sensitive to alternative specifications. Results on RTA membership remain globally qualitatively similar.
} 
Table 3: Impact of RTAs on war: Censored Probit model

\begin{tabular}{|c|c|c|c|c|c|c|c|c|c|c|}
\hline \multirow{2}{*}{$\begin{array}{l}\text { Model: } \\
\text { Dependent variable: } \\
\text { Deep RTA membership }\end{array}$} & \multicolumn{2}{|c|}{$\begin{array}{l}(1) \\
\text { MID Dispute }\end{array}$} & \multicolumn{2}{|c|}{$\begin{array}{c}(2) \\
\text { MID Dispute }\end{array}$} & \multicolumn{2}{|c|}{$\begin{array}{c}(3) \\
\text { MID Dispute }\end{array}$} & \multicolumn{2}{|c|}{$\begin{array}{c}(4) \\
\text { MID Dispute }\end{array}$} & \multicolumn{2}{|c|}{$\begin{array}{l}(5) \\
\text { MID Dispute }\end{array}$} \\
\hline & $\begin{array}{l}-0.68^{b} \\
(0.28)\end{array}$ & $\begin{array}{c}0.44^{a} \\
(0.09)\end{array}$ & $\begin{array}{c}-0.72^{a} \\
(0.28)\end{array}$ & $\begin{array}{l}0.43^{a} \\
(0.08)\end{array}$ & $\begin{array}{l}-0.46^{c} \\
(0.26)\end{array}$ & $\begin{array}{l}0.25^{a} \\
(0.09)\end{array}$ & $\begin{array}{l}-0.54^{b} \\
(0.27)\end{array}$ & $\begin{array}{l}0.40^{a} \\
(0.10)\end{array}$ & $\begin{array}{l}-0.53^{b} \\
(0.26)\end{array}$ & $\begin{array}{l}0.35^{a} \\
(0.08)\end{array}$ \\
\hline FTA membership & $\begin{array}{c}0.22 \\
(0.26)\end{array}$ & $\begin{array}{l}-0.31^{b} \\
(0.13)\end{array}$ & $\begin{array}{c}0.21 \\
(0.28)\end{array}$ & $\begin{array}{c}-0.33^{b} \\
(0.13)\end{array}$ & $\begin{array}{c}0.36 \\
(0.30)\end{array}$ & $\begin{array}{c}-0.43^{a} \\
(0.15)\end{array}$ & $\begin{array}{c}0.21 \\
(0.30)\end{array}$ & $\begin{array}{l}-0.10 \\
(0.15)\end{array}$ & $\begin{array}{c}0.27 \\
(0.29)\end{array}$ & $\begin{array}{l}-0.09 \\
(0.14)\end{array}$ \\
\hline PA membership & $\begin{array}{l}-0.00 \\
(0.12)\end{array}$ & $\begin{array}{c}0.02 \\
(0.06)\end{array}$ & $\begin{array}{l}-0.11 \\
(0.11)\end{array}$ & $\begin{array}{l}-0.05 \\
(0.05)\end{array}$ & $\begin{array}{l}-0.08 \\
(0.12)\end{array}$ & $\begin{array}{c}0.02 \\
(0.05)\end{array}$ & $\begin{array}{l}-0.11 \\
(0.13)\end{array}$ & $\begin{array}{l}0.24^{a} \\
(0.05)\end{array}$ & $\begin{array}{c}0.00 \\
(0.13)\end{array}$ & $\begin{array}{c}0.03 \\
(0.06)\end{array}$ \\
\hline PoA membership & $\begin{array}{c}0.06 \\
(0.21)\end{array}$ & $\begin{array}{l}0.31^{a} \\
(0.11)\end{array}$ & $\begin{array}{c}0.04 \\
(0.21)\end{array}$ & $\begin{array}{l}0.21^{c} \\
(0.12)\end{array}$ & $\begin{array}{l}0.05 \\
(0.21)\end{array}$ & $\begin{array}{c}0.27^{b} \\
(0.11)\end{array}$ & $\begin{array}{c}0.08 \\
(0.24)\end{array}$ & $\begin{array}{l}0.38^{a} \\
(0.13)\end{array}$ & $\left(\begin{array}{c}(0.10) \\
0.00 \\
(0.27)\end{array}\right.$ & $\begin{array}{l}0.39^{a} \\
(0.12)\end{array}$ \\
\hline Nbr of peaceful years & $\begin{array}{l}-0.01^{a} \\
(0.00)\end{array}$ & $\begin{array}{r}-0.00^{a} \\
(0.00)\end{array}$ & $\begin{array}{l}-0.01^{a} \\
(0.00)\end{array}$ & $\begin{array}{c}-0.00^{a} \\
(0.00)\end{array}$ & $\begin{array}{l}-0.01^{a} \\
(0.00)\end{array}$ & $\begin{array}{r}-0.00^{a} \\
(0.00)\end{array}$ & $\begin{array}{l}-0.01^{a} \\
(0.00)\end{array}$ & $\begin{array}{l}-0.00^{a} \\
(0.00)\end{array}$ & $\begin{array}{l}-0.01^{a} \\
(0.00)\end{array}$ & $\begin{array}{l}-0.00^{a} \\
(0.00)\end{array}$ \\
\hline ln distance & $\begin{array}{c}-0.16^{b} \\
(0.06)\end{array}$ & $\begin{array}{l}3.04^{a} \\
(0.51)\end{array}$ & $\begin{array}{l}-0.05 \\
(0.05)\end{array}$ & $\begin{array}{c}3.38^{a} \\
(0.51)\end{array}$ & $\begin{array}{l}-0.02 \\
(0.06)\end{array}$ & $\begin{array}{l}3.59^{a} \\
(0.52)\end{array}$ & $\begin{array}{l}-0.02 \\
(0.07)\end{array}$ & $\begin{array}{l}2.74^{a} \\
(0.44)\end{array}$ & $\begin{array}{l}-0.07 \\
(0.11)\end{array}$ & $\begin{array}{l}2.14^{a} \\
(0.48)\end{array}$ \\
\hline $\begin{array}{l}\text { Bil. trade dependence }(\mathrm{t}-5) \\
\text { (ln mean bil. imports / GDP) }\end{array}$ & $\begin{array}{r}-1.53^{a} \\
(0.45)\end{array}$ & $\begin{array}{l}-9.67^{a} \\
(1.84)\end{array}$ & $\begin{array}{l}-1.51^{a} \\
(0.43)\end{array}$ & $\begin{array}{c}-10.84^{a} \\
(1.82)\end{array}$ & $\begin{array}{r}-0.82^{c} \\
(0.42)\end{array}$ & $\begin{array}{c}-11.89^{a} \\
(1.89)\end{array}$ & $\begin{array}{l}-0.12 \\
(0.43)\end{array}$ & $\begin{array}{c}-10.16^{a} \\
(1.54)\end{array}$ & $\begin{array}{c}0.28 \\
(0.41)\end{array}$ & $\begin{array}{r}-8.40^{a} \\
(1.75)\end{array}$ \\
\hline $\begin{array}{l}\text { Multil. trade dependence (t-5) } \\
\text { (ln avg multi. import/ GDP) }\end{array}$ & $\begin{array}{l}-0.03 \\
(0.17)\end{array}$ & $\begin{array}{l}1.12^{b} \\
(0.45)\end{array}$ & $\begin{array}{c}0.06 \\
(0.15)\end{array}$ & $\begin{array}{l}1.38^{a} \\
(0.44)\end{array}$ & $\begin{array}{c}0.09 \\
(0.15)\end{array}$ & $\begin{array}{l}1.42^{a} \\
(0.44)\end{array}$ & $\begin{array}{c}(0.70) \\
0.20 \\
(0.14)\end{array}$ & $\begin{array}{l}2.10^{a} \\
(0.44)\end{array}$ & $\begin{array}{c}(0.11 \\
0.11)\end{array}$ & $\begin{array}{l}1.96^{a} \\
(0.41)\end{array}$ \\
\hline Zero trade dummy (t-5) & $\begin{array}{l}0.34^{a} \\
(0.13)\end{array}$ & $\begin{array}{r}-0.42^{a} \\
(0.03)\end{array}$ & $\begin{array}{l}0.38^{a} \\
(0.12)\end{array}$ & $\begin{array}{c}-0.41^{a} \\
(0.03)\end{array}$ & $\begin{array}{l}0.29^{b} \\
(0.13)\end{array}$ & $\begin{array}{c}-0.29^{a} \\
(0.03)\end{array}$ & $\begin{array}{c}(0.14) \\
0.14 \\
(0.16)\end{array}$ & $\begin{array}{r}-0.27^{a} \\
(0.03)\end{array}$ & $\begin{array}{c}0.10 \\
(0.15)\end{array}$ & $\begin{array}{r}-0.20^{a} \\
(0.03)\end{array}$ \\
\hline Contiguity & & & $\begin{array}{l}0.34^{a} \\
(0.12)\end{array}$ & $\begin{array}{l}0.45^{a} \\
(0.07)\end{array}$ & $\begin{array}{l}0.27^{b} \\
(0.12)\end{array}$ & $\begin{array}{c}0.51^{a} \\
(0.07)\end{array}$ & $\begin{array}{l}0.38^{b} \\
(0.16)\end{array}$ & $\begin{array}{l}0.63^{a} \\
(0.07)\end{array}$ & $\begin{array}{l}0.44^{a} \\
(0.15)\end{array}$ & $\begin{array}{l}0.38^{a} \\
(0.07)\end{array}$ \\
\hline sum of democracy indexes & & & & & $\begin{array}{r}-0.47^{a} \\
(0.07)\end{array}$ & $\begin{array}{c}0.29^{a} \\
(0.03)\end{array}$ & $\begin{array}{l}-0.43^{a} \\
(0.08)\end{array}$ & $\begin{array}{l}0.22^{a} \\
(0.03)\end{array}$ & $\begin{array}{l}-0.41^{a} \\
(0.08)\end{array}$ & $\begin{array}{l}0.22^{a} \\
(0.03)\end{array}$ \\
\hline UN vote correlation & & & & & & & $\begin{array}{c}0.20 \\
(0.20)\end{array}$ & $\begin{array}{r}-0.95^{a} \\
(0.05)\end{array}$ & $\begin{array}{c}0.28 \\
(0.31)\end{array}$ & $\begin{array}{r}-1.10^{a} \\
(0.05)\end{array}$ \\
\hline Colonial relationship & & & & & & & $\begin{array}{l}(0.20) \\
-0.17 \\
(0.13)\end{array}$ & $\begin{array}{l}0.35^{a} \\
(0.10)\end{array}$ & $\begin{array}{l}0.01 \\
-0.23 \\
(0.18)\end{array}$ & $\begin{array}{l}0.54^{a} \\
(0.08)\end{array}$ \\
\hline Common colonizer & & & & & & & $\left(\begin{array}{c}0.01 \\
(0.11)\end{array}\right.$ & $\begin{array}{l}0.10^{b} \\
(0.05)\end{array}$ & $\begin{array}{l}-0.06 \\
(0.12)\end{array}$ & $\begin{array}{l}0.15^{a} \\
(0.05)\end{array}$ \\
\hline sum $\ln$ areas & & & & & & & & & $\begin{array}{l}-0.01 \\
(0.04)\end{array}$ & $\begin{array}{l}0.13^{a} \\
(0.01)\end{array}$ \\
\hline Common defense alliance & & & & & & & & & $\begin{array}{l}-0.40^{b} \\
(0.17)\end{array}$ & $\begin{array}{l}0.54^{a} \\
(0.05)\end{array}$ \\
\hline Multil. trade dependence $*$ ldis t-5 & & $\begin{array}{l}1.59^{a} \\
(0.23)\end{array}$ & & $\begin{array}{l}1.73^{a} \\
(0.23)\end{array}$ & & $\begin{array}{l}1.83^{a} \\
(0.23)\end{array}$ & & $\begin{array}{l}1.52^{a} \\
(0.20)\end{array}$ & & $\begin{array}{l}1.24^{a} \\
(0.22)\end{array}$ \\
\hline Bil. trade dependence $*$ ldis t-5 & & $\begin{array}{l}-0.24^{a} \\
(0.05)\end{array}$ & & $\begin{array}{r}-0.27^{a} \\
(0.05)\end{array}$ & & $\begin{array}{r}-0.27^{a} \\
(0.05) \\
\end{array}$ & & $\begin{array}{l}-0.34^{a} \\
(0.05)\end{array}$ & & $\begin{array}{l}-0.26^{a} \\
(0.05)\end{array}$ \\
\hline Obse & & 0924 & & 0924 & & 13894 & & 31273 & & 8535 \\
\hline Uncensored Obs. & & 137 & & 0137 & & 210 & & 3025 & & 904 \\
\hline Log likelihood & -32 & 435.7 & -32 & 250.1 & -29 & 315.6 & -24 & 1475.9 & -23 & 3001.0 \\
\hline Wald test of indep.equations & & $48^{b}$ & & $.45^{a}$ & & $.85^{a}$ & & 2.46 & & 1.11 \\
\hline
\end{tabular}

Note: Robust standard errors adjusted for intragroup correlation in parentheses. a, b and c respectively denote significance at the $1 \%, 5 \%$ and $10 \%$ levels. Intercept and time dummies not reported. 
thus likely to be those found in our model to be signed by countries experiencing lots of disputes. The next section explicitly test it.

\section{RTA formation}

This section investigates the final result of the theoretical model, i.e. the determinants of different kind of regional integration. The econometric model, directly derived from equation 11, estimates for each kind of RTA the probability of its formation between two countries $i$ and $j$ at time $t$ using a probit model:

$$
\operatorname{Pr}\left(\operatorname{RTA}_{i j t}=1\right)=\beta_{0}+\beta_{1} \text { Dispute }_{i j t}+\beta_{2} \text { Controls }_{i j t}+\beta_{4} T_{t}+\epsilon_{i j t}
$$

Equation 11 states that integration is positively correlated to dispute occurrence $\rho$ if and only if the reduction of war probabilities more than compensate the higher opportunity cost of war among RTA members. If not, increasing international insecurity will lower integration incentives $\left(\beta_{1}>0\right.$ for deep RTAs and $\beta_{1}<0$ for shallow RTAs). Factors affecting incentives to form a RTA in the theoretical model are included as control variables: multilateral trade openness, heterogeneity costs of integration, i.e. geographical as well as cultural proximity of countries in the dyad, and, from equation 20 , and economic size of the partner country.

The probability of RTA between two countries is estimated every five years between 1980 and 2000 . Proximity is approximated by the distance between the most populated cities of the two countries and common border for its geographic part, and income level similarity (the log of the difference of income per capita) and dummies for common language and common colonizer for its cultural and historical part. Two proxy for economic size are included: the average GDP of countries in the dyad and the absolute difference in GDP.

As Baier and Bergstrand (2004) underline, endogeneity should be considered in our modeling strategy, because past RTA membership could impact current economic fundamentals of members. To deal with this endogeneity issue, three strategies are implemented.

- First, the variables of similarity of income per capita and GDP level and difference are lagged. Their 1960 value is used, which is a trade-off between data availability and length of the lag. This reduces our sample of countries, because several countries were not independent in 1960 .

- Concerning our variable of primary interest, dyadic dispute occurrence, a different strategy is implemented, in order to consider its evolution over time. An IV probit model is estimated, where dispute occurrence is determined endogenously, thanks to the use of exogenous instrumental variables. ${ }^{43}$ Theory in international relations gives us exogenous instrumental variables: the ratio of military capabilities (i.e. the ratio of lower to higher capacity index) and the major power status of countries in the dyad are highly correlated to dispute occurrence but not directly related to RTA membership. This former indicator is compiled by the COW project from six indicators:

\footnotetext{
${ }^{43}$ Another advantage of IV econometric models is that they also deal with measurement error of the endogenous explanatory variable, which is, as explained above, also valuable in our case.
} 
military expenditure, military personnel, energy consumption, iron and steel production, urban population, and total population. It is commonly used in political science to assess the relative national military capabilities. ${ }^{44}$

- Multilateral trade openness is also likely to be affected by past RTA membership. However, no appropriate instrumental variables are available, because standard geographical determinants of trade openness also affect RTA formation. A different procedure is implemented here to deal with this potential endogeneity bias: natural openness of countries in the dyad is controlled for by including the average of multilateral trade/GDP, lagged in 1960 to remote any effect of past RTA membership on current openness; and a proxy for world trade openness is added, - the average tariffs level for a sample of 28 countries $^{45}$-, which is exogenous to the dyad. The use of two different variables to account for countries natural propensity to trade on the one hand and the globalization trend, independently of the dyadic situation, on the other hand resolves the question of endogeneity linked to former arrangements.

Events data described in the previous section are used to construct a proxy for dispute propensity. The interstate dispute variable is defined as the dyadic dispute propensity over a 10 years period, lagged nine years to both prevent any simultaneity bias and take into account the time needed to negotiate an agreement. ${ }^{46}$ Because the traditional Sargan test is not applicable in our econometric specification, a Smith-Blundell test (with the probexog program) and a Wald test of exogeneity are implemented to test for the exogeneity of our model and the relevance of our two stage probit IV econometric specification. Both strongly confirm the need to account for endogeneity (first stage estimates are provided in Appendix C).

Econometric results from the preceding section showed that only the more integrated RTAs, such as common markets or custom unions, clearly provide security externalities. These kinds of RTAs are thus those likely to reduce war probabilities so as to more than compensate the higher potential loss from war among members. On the other side, free trade and preferential agreements do not entail enough political integration to exert any independent pacifying effect. They should be deterred by international insecurity. Hence, determinants of RTA formation between two countries are evaluated separately for the different kinds of agreements. Two categories are defined: deep RTAs which include custom union and common markets, and shallow RTAs, which gather together preferential and free trade agreements.

\footnotetext{
${ }^{44}$ More information is available from COW website: http://cow2.la.psu.edu/

${ }^{45}$ Argentina, Australia, Austria, Belgium, Canada, Chile, Denmark, Finland, France, Germany, Greece, Hong Kong, Indonesia, Ireland, Italy, Japan, Luxembourg, Malaysia, Netherlands, New Zealand, Norway, Philippines, Spain, Sweden, Switzerland, Thailand, United Kingdom, and United States. Data are assembled by Gwartney and Lawson (2005) from World Bank (Various issues) and other sources (see http://www.freetheworld.com for details).

${ }^{46}$ Finally, the data set includes 87 countries: Argentina, Australia, Austria, Belgium, Benin, Bolivia, Brazil, Bulgaria, Burkina Faso, Cameroon, Canada, Central African Republic, Chad, Chile, China, Colombia, Congo, Costa Rica, Czech Republic (Czechoslovakia in 1960), Democratic Republic of the Congo, Denmark, Dominican Republic, Ecuador, Egypt, El Salvador, Ethiopia, Finland, France, Gabon, Germany (German Federal Republic in 1960), Greece, Guatemala, Haiti, Honduras, Hungary, India, Indonesia, Iran, Iraq, Ireland, Israel, Italy, Ivory Coast, Japan, Jordan, Liberia, Madagascar, Malaysia, Mali, Mauritania, Mexico, Morocco, Nepal, Netherlands, New Zealand, Nicaragua, Niger, Nigeria, Norway, Pakistan, Panama, Paraguay, Peru, Philippines, Poland, Portugal, Romania, Russia, Saudi Arabia, Senegal, Somalia, South Africa, South Korea, Spain, Sri Lanka, Sudan, Sweden, Switzerland, Thailand, Togo, Tunisia, Turkey, United Kingdom, United States of America, Uruguay, Venezuela, and Yugoslavia.
} 


\section{$2.1 \quad$ Results}

Results are reported in table $4 .{ }^{47}$ First, simple probit estimation results for pooled RTAs are presented in column (1). Propensity to dispute is found to have a significant negative effect on RTA formation. Initial trade openness exhibit no significant coefficient whereas the average global tariffs level is found to be inversely related to RTA formation. That means that the freer trade is, the more incentives to integrate countries have. The probability of RTA significantly rises with the average GDP size of the two countries and if they are contiguous. On the contrary, a larger GDP and per capita GDP differential exerts a negative impact on RTA formation, as well as distance. Separating deep and shallow RTAs gives a slightly different picture (model (2)). Propensity to dispute is found to deter shallow RTAs, but has no significant impact on deep RTAs. These results are however potentially subject to an endogeneity bias, because it has been found that RTA membership affects the conflict process.

Specification (3) presents estimation results when dispute propensity is instrumented in order to account for any endogeneity biases. Dispute propensity is found to be significantly and strongly negatively associated to shallow RTAs and positively to deep RTAs, in accordance with our theoretical model. In addition, the average multilateral tariffs level is found to be negatively related to both deep and shallow RTA formation. This means that a more open international trade system fosters all kinds of regionalism. However, the initial level of trade openness has a different effect according to the kind of RTAs created. Natural openness to trade favors the creation of deep RTAs, but deters shallow RTAs. On the whole, countries more integrated to the world trading system are induced to create RTAs involving a large regional institutional framework. And this is all the more true the more globalized the world is. This is in line with North (1990, p.34), which states that "the greater the specialization and the number and variability of valuable attributes, the more weight must be put on reliable institutions that allow individuals to engage in complex contracting with a minimum of uncertainty about whether the terms of the contract can be realized". A broader supranational institutional framework would therefore allow country members to rely more heavily (be more dependent) on external trade. And this is more relevant the more integrated the whole world is, because further integration in a regional agreement would be deeper and thus necessitate more political institutions in a more globalized world. On the other hand, remote countries, which are less integrated to the world trading system, tend to form shallow RTAs.

Concerning other control variables, they globally exhibit the expected sign. Any form of regionalism is deterred by heterogeneity among countries. More distant countries, as well as countries whose income level is dissimilar, are significantly less likely to form any RTA, whereas adjacency increases only incentives to create shallow RTAs. Hence, geographic proximity is captured by distance for deep RTA, and by the common border dummy for shallow RTA. Sharing a common colonizer has no significant effect on incentives to integrate. Sharing a common official primary language favors the creation of shallow RTAs, but it is surprisingly negatively related to the probability to form a deep RTA. Concerning the size distribution of partner countries, as expected incentives to integrate increase with the economic size of member states, and, for shallow regionalism, the less unequal the size distribution.

\footnotetext{
${ }^{47}$ Time dummies and intercept are included but not reported.
} 
Table 4: Probabilities of RTA between two countries

\begin{tabular}{|c|c|c|c|c|c|c|c|}
\hline \multirow[t]{2}{*}{$\begin{array}{l}\text { Model: } \\
\text { Dependent variable: }\end{array}$} & \multirow{2}{*}{$\begin{array}{c}(1) \\
\text { all } \\
\text { RTAs }\end{array}$} & $\begin{array}{l}\text { Probit } \\
\quad(2 \\
\text { Shallow }\end{array}$ & Deep & \multicolumn{2}{|c|}{$\begin{array}{l}\text { IV Probit } \\
\text { (3) }\end{array}$} & \multicolumn{2}{|c|}{$\begin{array}{c}\text { IV Probit } \\
\text { (4) }\end{array}$} \\
\hline & & RTAs & RTAs & RTAs & RTAs & RTAs & RTAs \\
\hline Propensity to dispute & $\begin{array}{l}-0.49^{a} \\
(0.17)\end{array}$ & $\begin{array}{l}-0.43^{b} \\
(0.21)\end{array}$ & $\begin{array}{l}-0.04 \\
(0.27)\end{array}$ & $\begin{array}{l}-4.85^{a} \\
(0.35)\end{array}$ & $\begin{array}{l}1.69^{c} \\
(0.90)\end{array}$ & $\begin{array}{l}-5.77^{a} \\
(0.35)\end{array}$ & $\begin{array}{l}3.11^{a} \\
(0.87)\end{array}$ \\
\hline Multil. trade (1960) & $\begin{array}{c}0.01 \\
(0.10)\end{array}$ & $\begin{array}{l}-0.39^{a} \\
(0.10)\end{array}$ & $\begin{array}{l}2.19^{a} \\
(0.26)\end{array}$ & $\begin{array}{l}-0.39^{a} \\
(0.08)\end{array}$ & $\begin{array}{l}2.15^{a} \\
(0.26)\end{array}$ & $\begin{array}{l}-0.31^{a} \\
(0.08)\end{array}$ & $\begin{array}{l}1.88^{a} \\
(0.29)\end{array}$ \\
\hline Multi. Tariffs & $\begin{array}{l}-0.10^{a} \\
(0.01)\end{array}$ & $\begin{array}{l}-0.08^{a} \\
(0.01)\end{array}$ & $\begin{array}{l}-0.21^{a} \\
(0.02)\end{array}$ & $\begin{array}{l}-0.05^{a} \\
(0.01)\end{array}$ & $\begin{array}{c}-0.20^{a} \\
(0.02)\end{array}$ & $\begin{array}{l}-0.07^{a} \\
(0.01)\end{array}$ & $\begin{array}{c}-0.16^{a} \\
(0.02)\end{array}$ \\
\hline ln distance & $\begin{array}{l}-0.29^{a} \\
(0.04)\end{array}$ & $\begin{array}{c}0.03 \\
(0.05)\end{array}$ & $\begin{array}{r}-1.34^{a} \\
(0.09)\end{array}$ & $\begin{array}{l}-0.10^{b} \\
(0.04)\end{array}$ & $\begin{array}{r}-1.25^{a} \\
(0.11)\end{array}$ & $\begin{array}{l}-0.02 \\
(0.05)\end{array}$ & $\begin{array}{l}-0.99^{a} \\
(0.12)\end{array}$ \\
\hline Contiguity & $\begin{array}{l}0.68^{a} \\
(0.15)\end{array}$ & $\begin{array}{l}0.87^{a} \\
(0.16)\end{array}$ & $\begin{array}{l}-0.03 \\
(0.24)\end{array}$ & $\begin{array}{l}1.40^{a} \\
(0.19)\end{array}$ & $\begin{array}{l}-0.31 \\
(0.25)\end{array}$ & $\begin{array}{l}1.45^{a} \\
(0.20)\end{array}$ & $\begin{array}{l}-0.30 \\
(0.25)\end{array}$ \\
\hline Diff. GDP per cap. (1960) & $\begin{array}{l}-0.21^{a} \\
(0.02)\end{array}$ & $\begin{array}{l}-0.19^{a} \\
(0.02)\end{array}$ & $\begin{array}{l}-0.13^{a} \\
(0.04)\end{array}$ & $\begin{array}{l}-0.12^{a} \\
(0.02)\end{array}$ & $\begin{array}{r}-0.12^{a} \\
(0.04)\end{array}$ & $\begin{array}{l}-0.05^{b} \\
(0.02)\end{array}$ & $\begin{array}{l}-0.12^{b} \\
(0.06)\end{array}$ \\
\hline Common language & $\begin{array}{c}0.08 \\
(0.09)\end{array}$ & $\begin{array}{l}0.27^{a} \\
(0.09)\end{array}$ & $\begin{array}{l}-0.49^{b} \\
(0.23)\end{array}$ & $\begin{array}{l}0.46^{a} \\
(0.08)\end{array}$ & $\begin{array}{c}-0.61^{a} \\
(0.23)\end{array}$ & $\begin{array}{c}0.19^{b} \\
(0.08)\end{array}$ & $\begin{array}{c}-0.84^{a} \\
(0.20)\end{array}$ \\
\hline Common colonizer & $\begin{array}{l}-0.18 \\
(0.15)\end{array}$ & $\begin{array}{l}-0.19 \\
(0.16)\end{array}$ & $\begin{array}{l}0.62^{b} \\
(0.31)\end{array}$ & $\begin{array}{c}0.05 \\
(0.14)\end{array}$ & $\begin{array}{c}0.48 \\
(0.31)\end{array}$ & $\begin{array}{l}0.29^{b} \\
(0.14)\end{array}$ & $\begin{array}{l}1.58^{a} \\
(0.35)\end{array}$ \\
\hline Avg. GDP (1960) & $\begin{array}{l}0.27^{a} \\
(0.04)\end{array}$ & $\begin{array}{l}0.15^{a} \\
(0.04)\end{array}$ & $\begin{array}{l}0.48^{a} \\
(0.09)\end{array}$ & $\begin{array}{l}0.36^{a} \\
(0.04)\end{array}$ & $\begin{array}{c}0.30^{b} \\
(0.12)\end{array}$ & $\begin{array}{l}0.46^{a} \\
(0.03)\end{array}$ & $\begin{array}{l}-0.13 \\
(0.13)\end{array}$ \\
\hline Diff. GDP (1960) & $\begin{array}{l}-0.18^{a} \\
(0.03)\end{array}$ & $\begin{array}{l}-0.16^{a} \\
(0.03)\end{array}$ & $\begin{array}{l}-0.01 \\
(0.06)\end{array}$ & $\begin{array}{l}-0.16^{a} \\
(0.03)\end{array}$ & $\begin{array}{c}0.00 \\
(0.05)\end{array}$ & $\begin{array}{l}-0.17^{a} \\
(0.03)\end{array}$ & $\begin{array}{c}0.10 \\
(0.06)\end{array}$ \\
\hline $\begin{array}{l}\text { Sum of democracy indexes } \\
\text { Common defence alliance }\end{array}$ & & & & & & $\begin{array}{l}-0.39^{a} \\
(0.06) \\
0.81^{a} \\
(0.11)\end{array}$ & $\begin{array}{l}2.60^{a} \\
(0.37) \\
0.62^{a} \\
(0.18)\end{array}$ \\
\hline Observations & 12445 & 12445 & 12445 & 12445 & 12445 & 11698 & 11698 \\
\hline Log pseudolikelihood & -3856.5 & -3434.3 & -604.4 & 2996.4 & 5726.1 & 3182.7 & 5760.9 \\
\hline Wald test of exogeneity & & & & $65.6^{a}$ & $3.9^{b}$ & $50.0^{a}$ & $9.5^{a}$ \\
\hline Smith-Blundell test of exogeneity & & & & $128.6^{a}$ & $11.2^{a}$ & $156.3^{a}$ & $22.8^{a}$ \\
\hline
\end{tabular}

Note: Robust standard errors adjusted for intragroup correlation in parentheses. a, b and c respectively denote significance at the $1 \%, 5 \%$ and $10 \%$ levels. Time dummies and intercept are not reported.

Two important control variables, not directly derived from the model, are added in the last specification of table 4, because they are likely to affect both RTA formation and dispute occurrence: the level of democracy and a dummy variable for countries sharing a common defense alliance. Some empirical evidences show that more democratic countries are more likely to form RTAs (Mansfield et al., 2002). On the other side, democratic status is also likely to affect dispute occurrence. Its omission could thus bias the results. In addition, it is likely that citizens from democratic countries share common preferences, which reduces heterogeneity costs of political integration. Similarly, sharing a common defence alliance could affect both the RTA membership and the way conflicts are settled. Results strongly confirm that sharing a defence alliance foster the probability for two countries to form any RTA. Concerning democracy, dyads exhibiting on average more democratic institutions have a higher probability to form a deep RTA, whereas shallow RTAs are less likely in democratic dyads. Disentangling different forms of regionalism is thus particularly important to understand how domes- 
tic institutions affect the formation of such international agreements. This seems logical in the sense that entering a deep RTA involves to share some common supranational institutions or public goods. To give up such a part of the national sovereignty is possible only between similar countries in terms of political system, form of government and origin of the legitimacy. This constraint is less binding concerning shallow RTAs, in which more autocratic regimes can retain more independent power while benefiting from gains from trade. The inclusion of these two additional control does not significantly alter previous results. Interestingly, the positive coefficient on the common colonizer dummy turns significant for all kind of agreements. In this complete (and preferred) specification, results strongly, and significantly at the $1 \%$ level, confirm the theoretical prediction: countries more subject to interstate disputes integrate more deeply, whereas international insecurity reduces incentives to form shallow RTAs.

\subsection{Robustness check}

In order to check the robustness of our results, several alternative specification of the model are ran. First, to test for any sample bias due to the presence of the EU country members, which belong to Western Europe an historically particularly integrated region, the preferred specification (4) is reestimated on a restricted sample, excluding Western European dyads. Results are presented in the first columns of table 5. Our main results remain qualitatively unchanged. In the deep RTA case, the significance of the coefficient on dispute propensity is however reduced, which arises because excluding Western European dyads largely reduces the number of dyads having a deep RTA. Hence, our results are robust to the exclusion of the historically and geographically most integrated region of the world, Western Europe.

The estimation is then restricted to the year 2000. This specification is thus closer to the model estimated by Baier and Bergstrand (2004), focusing on cross-country variation in RTA membership. Time variation in RTA membership is not accounted for, and the evolution of global tariffs is hence not included in the model. The instrumented RHS variable, dispute occurrence, is computed over the whole period. Specification (6) in table 5 presents the results. Overall, results are consistent with previous findings. Dispute propensity again affects strongly and negatively shallow regionalism but positively deep regionalism, with coefficients significant at the $1 \%$ level. However, lagged trade openness is found to strongly foster the formation of deep as well as shallow RTAs. In this specification, lagged trade openness is a proxy for both natural openness to trade and the degree of liberalization of the world trade system. As in preceding specifications, this effect is however stronger for deep than for shallow regionalism. Coefficients on other control variables remains qualitatively identical.

Finally, the definition of RTAs used so far could induce a selection bias, because it restricts the sample of agreements included in the dependent variables. Specification (6) is re-estimated using a wider definition of trading agreements. The new dependent variables include all trade arrangements which take the form of Preferential Trading Arrangement and Free Trade Area on the one hand, and Customs Union and Common market on the other. All bilateral trading agreements are thus added to our list of RTAs (see appendix B for a list of agreements included). Moreover, a dummy for countries 
ever in a colonial relationship is added. The inclusion of this variable was impossible before because, according to the initial definition of RTAs adopted in this paper, no such countries entered a regional agreement. Results, provided in specification (7) in table 5, confirm previous findings. Results are thus robust to alternative definition of the dependent variable, such as the wide definition of trading agreements adopted in specification (7).

Table 5: Probabilities of RTA between two countries (IV Probit)

\begin{tabular}{|c|c|c|c|c|c|c|}
\hline \multirow{2}{*}{$\begin{array}{l}\text { Model: } \\
\text { Dependent variable: }\end{array}$} & \multicolumn{2}{|c|}{$\begin{array}{c}\text { Western European } \\
\text { dyads excluded } \\
(5)\end{array}$} & \multicolumn{2}{|c|}{$\begin{array}{c}\text { Year } 2000 \\
(6)\end{array}$} & \multicolumn{2}{|c|}{$\begin{array}{c}\text { Year } 2000 \text { and } \\
\text { bil. RTAs } \\
(7)\end{array}$} \\
\hline & $\begin{array}{l}\text { Shallow } \\
\text { RTAs }\end{array}$ & $\begin{array}{l}\text { Deep } \\
\text { RTAs }\end{array}$ & $\begin{array}{l}\text { Shallow } \\
\text { RTAs }\end{array}$ & $\begin{array}{l}\text { Deep } \\
\text { RTAs }\end{array}$ & $\begin{array}{l}\text { Shallow } \\
\text { RTAs }\end{array}$ & $\begin{array}{l}\text { Deep } \\
\text { RTAs }\end{array}$ \\
\hline Propensity to dispute & $\begin{array}{r}-5.62^{a} \\
(0.33)\end{array}$ & $\begin{array}{l}1.97^{c} \\
(1.18)\end{array}$ & $\begin{array}{r}-10.59^{a} \\
(0.61)\end{array}$ & $\begin{array}{l}4.69^{a} \\
(1.31)\end{array}$ & $\begin{array}{l}-8.41^{a} \\
(0.70)\end{array}$ & $\begin{array}{l}4.69^{a} \\
(1.31)\end{array}$ \\
\hline Multil. trade (1960) & $\begin{array}{l}-0.25^{a} \\
(0.08)\end{array}$ & $\begin{array}{l}0.65^{b} \\
(0.33)\end{array}$ & $\begin{array}{l}0.21^{a} \\
(0.07)\end{array}$ & $\begin{array}{l}1.06^{a} \\
(0.23)\end{array}$ & $\begin{array}{l}0.37^{a} \\
(0.08)\end{array}$ & $\begin{array}{l}1.06^{a} \\
(0.23)\end{array}$ \\
\hline Multi. tariffs & $\begin{array}{l}-0.05^{a} \\
(0.01)\end{array}$ & $\begin{array}{l}-0.13^{a} \\
(0.02)\end{array}$ & & & & \\
\hline ln distance & $\begin{array}{l}-0.08 \\
(0.06)\end{array}$ & $\begin{array}{l}-0.59^{a} \\
(0.11)\end{array}$ & $\begin{array}{c}0.06 \\
(0.05)\end{array}$ & $\begin{array}{r}-0.96^{a} \\
(0.09)\end{array}$ & $\begin{array}{l}-0.24^{a} \\
(0.04)\end{array}$ & $\begin{array}{l}-0.96^{a} \\
(0.09)\end{array}$ \\
\hline contiguity & $\begin{array}{l}1.56^{a} \\
(0.23)\end{array}$ & $\begin{array}{c}0.07 \\
(0.38)\end{array}$ & $\begin{array}{l}1.41^{a} \\
(0.22)\end{array}$ & $\begin{array}{l}-0.11 \\
(0.27)\end{array}$ & $\begin{array}{l}0.91^{a} \\
(0.20)\end{array}$ & $\begin{array}{l}-0.11 \\
(0.27)\end{array}$ \\
\hline Diff. GDP per cap. (1960) & $\begin{array}{l}-0.08^{a} \\
(0.02)\end{array}$ & $\begin{array}{c}0.02 \\
(0.07)\end{array}$ & $\begin{array}{l}-0.13^{a} \\
(0.02)\end{array}$ & $\begin{array}{c}0.07 \\
(0.05)\end{array}$ & $\begin{array}{l}-0.16^{a} \\
(0.02)\end{array}$ & $\begin{array}{c}0.07 \\
(0.05)\end{array}$ \\
\hline Common language & $\begin{array}{l}0.17^{b} \\
(0.08)\end{array}$ & $\begin{array}{l}-0.55^{b} \\
(0.23)\end{array}$ & $\begin{array}{l}0.30^{a} \\
(0.08)\end{array}$ & $\begin{array}{l}-0.62^{a} \\
(0.19)\end{array}$ & $\begin{array}{c}0.09 \\
(0.08)\end{array}$ & $\begin{array}{l}-0.62^{a} \\
(0.19)\end{array}$ \\
\hline Common colonizer & $\begin{array}{l}0.25^{c} \\
(0.13)\end{array}$ & $\begin{array}{l}1.89^{a} \\
(0.32)\end{array}$ & $\begin{array}{c}0.10 \\
(0.12)\end{array}$ & $\begin{array}{l}2.20^{a} \\
(0.31)\end{array}$ & $\begin{array}{l}-0.10 \\
(0.14)\end{array}$ & $\begin{array}{l}2.20^{a} \\
(0.31)\end{array}$ \\
\hline Colonial relationships & & & & & $\begin{array}{l}0.50^{c} \\
(0.25)\end{array}$ & \\
\hline Avg. GDP (1960) & $\begin{array}{l}0.47^{a} \\
(0.04)\end{array}$ & $\begin{array}{l}-0.22^{b} \\
(0.11)\end{array}$ & $\begin{array}{l}0.53^{a} \\
(0.04)\end{array}$ & $\begin{array}{l}-0.12 \\
(0.10)\end{array}$ & $\begin{array}{l}0.70^{a} \\
(0.04)\end{array}$ & $\begin{array}{l}-0.12 \\
(0.10)\end{array}$ \\
\hline Diff. GDP (1960) & $\begin{array}{r}-0.17^{a} \\
(0.03)\end{array}$ & $\begin{array}{c}0.01 \\
(0.06)\end{array}$ & $\begin{array}{r}-0.17^{a} \\
(0.02)\end{array}$ & $\begin{array}{l}-0.03 \\
(0.05)\end{array}$ & $\begin{array}{r}-0.27^{a} \\
(0.03)\end{array}$ & $\begin{array}{l}-0.03 \\
(0.05)\end{array}$ \\
\hline Sum of democracy indexes & $\begin{array}{l}-0.29^{a} \\
(0.05)\end{array}$ & $\begin{array}{l}0.65^{a} \\
(0.22)\end{array}$ & $\begin{array}{l}-0.37^{a} \\
(0.07)\end{array}$ & $\begin{array}{l}2.27^{a} \\
(0.34)\end{array}$ & $\begin{array}{c}-0.29^{a} \\
(0.06)\end{array}$ & $\begin{array}{l}2.27^{a} \\
(0.34)\end{array}$ \\
\hline Common defence alliance & $\begin{array}{l}0.83^{a} \\
(0.12)\end{array}$ & $\begin{array}{l}1.34^{a} \\
(0.27)\end{array}$ & $\begin{array}{l}0.72^{a} \\
(0.11)\end{array}$ & $\begin{array}{l}0.53^{a} \\
(0.17)\end{array}$ & $\begin{array}{l}0.50^{a} \\
(0.10)\end{array}$ & $\begin{array}{l}0.53^{a} \\
(0.17)\end{array}$ \\
\hline Observations & 11200 & 11200 & 3347 & 3347 & 3347 & 3347 \\
\hline Log pseudolikelihood & 3097.1 & 5873.2 & 2659.5 & 3587.6 & 2359.0 & 3587.6 \\
\hline Wald test of exogeneity & $61.4^{a}$ & $4.2^{b}$ & $88.4^{a}$ & $12.5^{a}$ & $65.1^{a}$ & $12.5^{a}$ \\
\hline Smith-Blundell test of exogeneity & $156.3^{a}$ & $22.8^{a}$ & $84.0^{a}$ & $9.4^{a}$ & $79.5^{a}$ & $9.4^{a}$ \\
\hline
\end{tabular}

Note: Robust standard errors adjusted for intragroup correlation in parentheses. a, $\mathrm{b}$ and $\mathrm{c}$ respectively denote significance at the $1 \%, 5 \%$ and $10 \%$ levels. Intercept not reported. 


\section{Conclusion}

This paper is the first to investigate, both theoretically and empirically, why RTAs take different forms around the world. By introducing simultaneously military and trade issues in a model of political integration, this paper sheds light on the interplays between security and economic forces in the formation of RTAs. This work puts forward that defining the depth of regional integration by the level of political integration it entails is necessary to understand the determinants of the form taken by regionalism. Results emphasize that different kinds of RTAs have different determinants. Countries more subject to interstate disputes are more likely to form politically integrated regional agreements, such as common market or custom union. On the contrary, international insecurity deters less integrated agreements implying a weak institutional framework, such as preferential or free trade agreements. Besides their potential effect on trade, analyzing RTAs as regulation institutions in a world where no supranational institution enforces property rights is therefore particularly relevant. In order to remain sustainable, greater national dependence on external trade necessitates guarantees on the continuity of access to world markets, i.e. that interstates disputes would not disrupt economic flows. Such regulation is typically the purpose of institutions, such as those created with the more integrated RTAs.

These results have important implications concerning the nexus between multilateralism and regionalism. Indeed, the positive security externality of RTAs highlighted in this paper suggests that institutions created along with regional integration are a prerequisite to market integration, which could doubtfully been provided at the multilateral level. Regionalism and multilateralism would therefore be complementary as far as the former encourage countries to put less emphasis on matter of security and to be more dependent on external trade. Our results are thus in line with Ethier (1998), who relates the recent surge of regionalism to multilateral trade liberalization, and argues that multilateral and regional trade integration are mutually reinforcing.

Further work is needed to deepen our understanding of the interplays between globalization and political integration. In particular, extension of this work towards the idea developed by Rodrik (2000), that integrated national economies, nation state and mass politics defined an extended trilemma, only two out of three can be picked. Globalization, because it involves an harmonization of domestic standards, regulations or tax policies, would therefore comes at the expense of either state sovereignty or participatory rate of the political system. As it is defined here, deep regionalism can be understood in this framework as an intermediate organization federalizing national economic policy between countries whose preference are close. 


\section{Appendix A: Proofs}

\section{Defense spending:}

Each country chooses its level of defense spending while taking into account defense spending of its potential opponents, its neighbors. Thus, without RTA, the Nash equilibrium defense spending are:

$$
\begin{aligned}
& d_{1}^{*}=\max _{d_{1}}\left\{\frac{\rho \pi}{4}\left[2 R \frac{d_{1}}{d_{1}+d_{2}^{*}}-\theta+2 R \frac{d_{1}}{d_{1}+d_{4}^{*}}-\theta\right]+\left(1-\frac{\rho \pi}{2}\right) R-d_{1}\right\} \\
& d_{2}^{*}=\max _{d_{2}}\left\{\frac{\rho \pi}{4}\left[2 R \frac{d_{2}}{d_{2}+d_{1}^{*}}-\theta+2 R \frac{d_{2}}{d_{2}+d_{3}^{*}}-\theta\right]+\left(1-\frac{\rho \pi}{2}\right) R-d_{2}\right\} \\
& d_{3}^{*}=\max _{d_{3}}\left\{\frac{\rho \pi}{4}\left[2 R \frac{d_{3}}{d_{3}+d_{2}^{*}}-\theta+2 R \frac{d_{3}}{d_{3}+d_{4}^{*}}-\theta\right]+\left(1-\frac{\rho \pi}{2}\right) R-d_{3}\right\} \\
& d_{4}^{*}=\max _{d_{4}}\left\{\frac{\rho \pi}{4}\left[2 R \frac{d_{4}}{d_{4}+d_{1}^{*}}-\theta+2 R \frac{d_{4}}{d_{4}+d_{3}^{*}}-\theta\right]+\left(1-\frac{\rho \pi}{2}\right) R-d_{4}\right\}
\end{aligned}
$$

whose first order conditions give:

$$
\begin{array}{r}
\frac{d_{2}}{\left(d_{1}+d_{2}\right)^{2}}+\frac{d_{4}}{\left(d_{1}+d_{4}\right)^{2}}=\frac{d_{1}}{\left(d_{2}+d_{1}\right)^{2}}+\frac{d_{3}}{\left(d_{2}+d_{3}\right)^{2}}= \\
\frac{d_{4}}{\left(d_{3}+d_{4}\right)^{2}}+\frac{d_{2}}{\left(d_{3}+d_{2}\right)^{2}}=\frac{d_{1}}{\left(d_{4}+d_{1}\right)^{2}}+\frac{d_{3}}{\left(d_{4}+d_{3}\right)^{2}}=\frac{2}{\rho \pi R}
\end{array}
$$

The solution is:

$$
d_{1}^{*}=d_{2}^{*}=d_{3}^{*}=d_{4}^{*}=\frac{\rho \pi R}{4}
$$

With $\mathrm{RTA}^{48}$, the Nash equilibrium defense spending are defined by:

$$
\begin{aligned}
& d_{1}^{*}=\max _{d_{1}}\left\{\frac{\rho \pi^{R T A}}{4}\left[2 R \frac{d_{1}}{d_{1}+d_{2}^{*}}-1\right]+\frac{\rho \pi}{4}\left[2 R \frac{d_{1}}{d_{1}+d_{4}^{*}}-\theta\right]+\left(1-\frac{\rho\left(\pi+\pi^{R T A}\right)}{4}\right) R-d_{1}\right\} \\
& d_{2}^{*}=\max _{d_{2}}\left\{\frac{\rho \pi^{R T A}}{4}\left[2 R \frac{d_{2}}{d_{2}+d_{1}^{*}}-1\right]+\frac{\rho \pi}{4}\left[2 R \frac{d_{2}}{d_{2}+d_{3}^{*}}-\theta\right]+\left(1-\frac{\rho\left(\pi+\pi^{R T A}\right)}{4}\right) R-d_{2}\right\} \\
& d_{3}^{*}=\max _{d_{3}}\left\{\frac{\rho \pi^{R T A}}{4}\left[2 R \frac{d_{3}}{d_{3}+d_{4}^{*}}-1\right]+\frac{\rho \pi}{4}\left[2 R \frac{d_{3}}{d_{3}+d_{2}^{*}}-\theta\right]+\left(1-\frac{\rho\left(\pi+\pi^{R T A}\right)}{4}\right) R-d_{3}\right\} \\
& d_{4}^{*}=\max _{d_{4}}\left\{\frac{\rho \pi^{R T A}}{4}\left[2 R \frac{d_{4}}{d_{4}+d_{3}^{*}}-1\right]+\frac{\rho \pi}{4}\left[2 R \frac{d_{4}}{d_{4}+d_{1}^{*}}-\theta\right]+\left(1-\frac{\rho\left(\pi+\pi^{R T A}\right)}{4}\right) R-d_{4}\right\}
\end{aligned}
$$

The solution is:

$$
d_{1}^{*}=d_{2}^{*}=d_{3}^{*}=d_{4}^{*}=\frac{\rho R\left(\pi+\pi^{R T A}\right)}{8}
$$

\section{The decision to form a RTA:}

Regional integration is strictly preferred to independence if $U_{R T A}>U_{\text {ind }}$. From equation 1, we know that gains from regional integration arise from 3 sources: market size, conflict and relative defense

\footnotetext{
${ }^{48}$ Because opportunity costs are equal on each continent and countries are symmetric, only two world configurations are possible: one without regional integration and one with one RTA on each continent. For opportunity costs differing on each continent, analytical results can be derived but are awkwardly complicated.
} 
spending. Those gains should balance heterogeneity costs from integration k, such that:

$$
\left(Y_{i}^{R T A}-Y_{i}^{i n d}\right)+\left(R_{i}^{R T A}-R_{i}^{i n d}\right)-\left(d_{i}^{R T A}-d_{i}^{i n d}\right)>k
$$

Substituting with equation 3,8 and 10, we obtain:

$$
(1-\theta)-\frac{\rho}{4}\left[\pi^{R T A}-\pi \theta\right]-\frac{\rho R}{8}\left[\pi^{R T A}-\pi\right]>k
$$

Hence, regional integration is preferred to independence if and only if:

$$
\frac{\rho}{8}\left[\pi(2 \theta+R)-\pi^{R T A}(2+R)\right]+1-\theta>k
$$

\section{The decision to form a RTA (asymmetric case):}

As above, regional integration is strictly preferred to independence if:

$$
\left(Y_{i}^{R T A}-Y_{i}^{i n d}\right)+\left(R_{i}^{R T A}-R_{i}^{i n d}\right)-\left(d_{i}^{R T A}-d_{i}^{i n d}\right)>k
$$

From 14, we have:

$$
Y_{i}^{R T A}-Y_{i}^{i n d}= \begin{cases}1-\sigma+\theta(\sigma-1) & \text { if } i \neq k \text { and i belongs to the Western continent } \\ 1+2 \sigma-\theta(1+3 \sigma) & \text { else }\end{cases}
$$

and

$R_{i}^{R T A}-R_{i}^{i n d}= \begin{cases}\frac{\rho}{4}\left(\pi \theta(1+3 \sigma)-\pi^{R T A}(1+3 \sigma)\right) & \text { if } i \neq k \text { and i belongs to the Western continent } \\ \frac{\rho}{4}\left(\pi \theta(1-\sigma)-\pi^{R T A}(1-\sigma)\right) & \text { else }\end{cases}$

Defense spending do not vary from the symmetric case. Hence, gains from integration are higher for a small country entering a union with a large partner. But both countries must agree for a RTA to be formed. So regional integration is chosen by countries $i$ and $j$ if and only if:

$$
\frac{\rho}{8}\left[\pi^{R T A}(2-2 \sigma+R)-\pi(2 \theta-2 \sigma \theta+R)\right]+(1-\theta)(1-\sigma)>k
$$




\section{Appendix B1: Regional Trading Agreements}

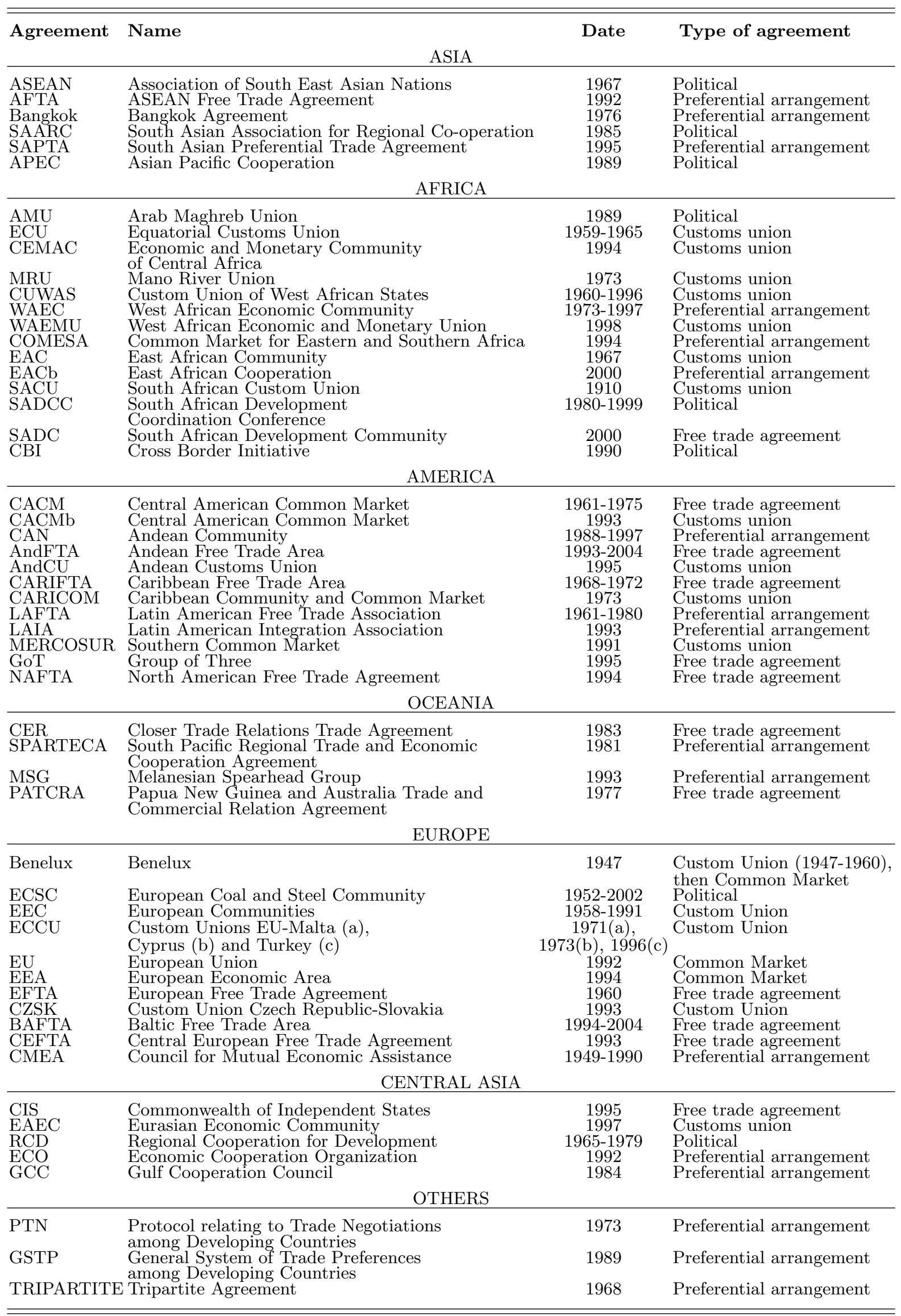




\section{Appendix B2: Bilateral Trading Agreements}

\begin{tabular}{lc|lc}
\hline \hline Agreement & $\begin{array}{c}\text { Year of entry } \\
\text { into force }\end{array}$ & Agreement & $\begin{array}{c}\text { Year of entry } \\
\text { into force }\end{array}$ \\
\hline Bulgaria - Turkey & 1999 & EU - Tunisia & 1998 \\
Canada - Chile & 1997 & EFTA - Bulgaria & 1993 \\
Canada - Israel & 1997 & EFTA - Czech Republic & 1992 \\
CARICOM - Columbia & 1995 & EFTA - Hungary & 1993 \\
CARICOM - Venezuela & 1993 & EFTA - Israel & 1993 \\
CARICOM - Dominican Republic & 1998 & EFTA - Morocco & 1999 \\
Chile - Mexico & 1999 & EFTA - Poland & 1993 \\
Chile - Peru & 1998 & EFTA - Romania & 1993 \\
Chile - Bolivia & 1993 & EFTA - Turkey & 1992 \\
Chile - Colombia & 1994 & Hungary - Israel & 1998 \\
Chile - Venezuela & 1993 & Hungary - Turkey & 1998 \\
Czech Republic - Israel & 1997 & India - Sri Lanka & 1998 \\
Czech Republic - Turkey & 1998 & India - Nepal & 1996 \\
EU - Bulgaria & 1994 & Israel - Turkey & 1997 \\
EU - Czech Republic & 1992 & MERCOSUR - Chile & 1996 \\
EU - Egypt & 1977 & MERCOSUR - Bolivia & 1996 \\
EU - Hungary & 1992 & Mexico - Israel & 2000 \\
EU - Israel & 2000 & Mexico - Bolivia & 1995 \\
EU - Mexico & 2000 & Mexico - Costa Rica & 1995 \\
EU - Morocco & 2000 & Mexico - Nicaragua & 1998 \\
EU - Poland & 1992 & Poland - Israel & 1998 \\
EU - Romania & 1993 & Poland - Turkey & 2000 \\
EU - South Africa & 2000 & Romania - Turkey & 1998 \\
EU - Switzerland & 1973 & United States - Israel & 1985 \\
\hline \hline
\end{tabular}




\section{Appendix C: First stage regressions}

Table 6: First stage estimates

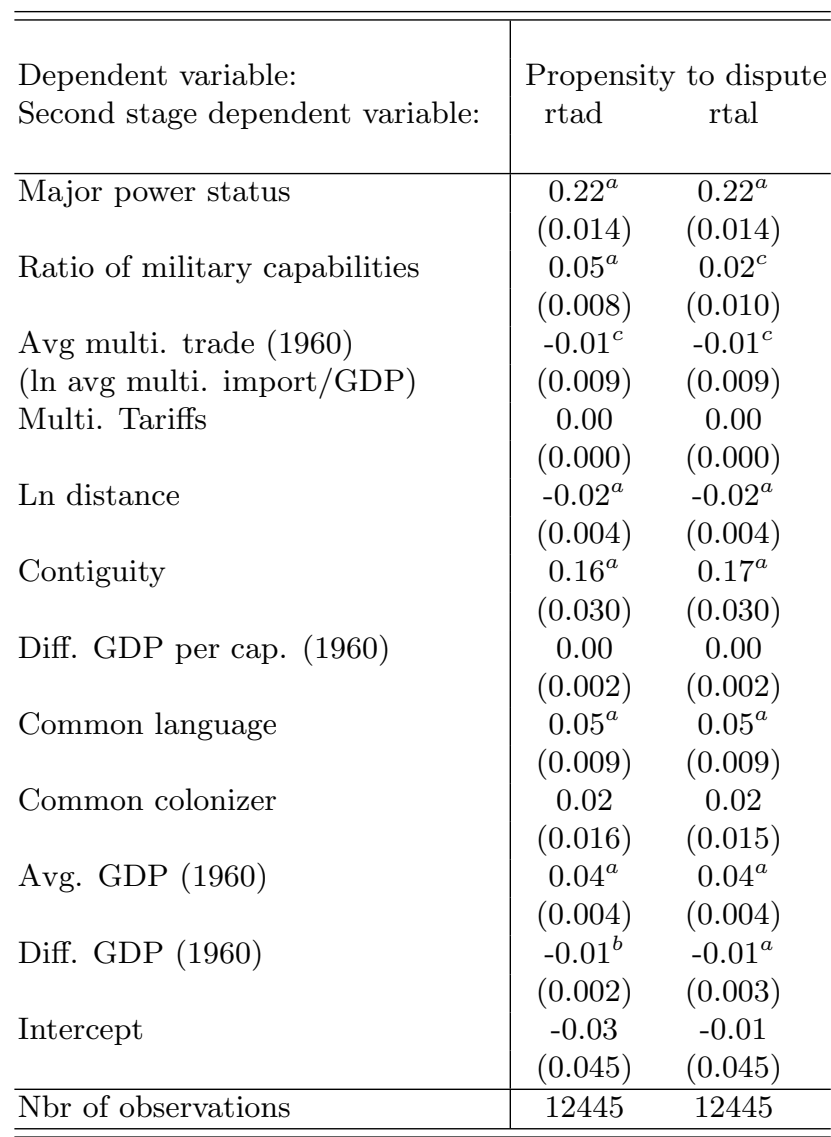

Note: Robust standard errors adjusted for intragroup correlation in parentheses. a, b and c respectively denote significance at the $1 \%, 5 \%$ and $10 \%$ levels. Time dummies are not reported. 


\section{References}

Alesina, Alberto and Enrico Spolaore, "On the number and Size of Nations," The Quarterly Journal of Economics, 1997, 92 (4), 1027-1056.

_ and _, The Size of Nations, MIT Press, Cambridge MA, 2003.

_ and _ , "International Conflict, Defense Spending and the Size of Countries," European Economic Review, Forthcoming.

- and Romain Wacziarg, "Is Europe Going too far?," Carnegie-Rochester Conference Series on Public Policy (supplement of Journal of Monetary Economics), 1999, 51, 1-42.

_ , Enrico Spolaore, and Romain Wacziarg, "Economic Integration and Political Disintegration," American Economic Review, 2000, 90 (December), 1276-1296.

_ , Roberto Perotti, and Enrico Spolaore, "Together or separately? Issues on the costs and benefits of political and fiscal unions," European Economic Review, 1995, 39, 751-758.

Baier, Scott L and Jeffrey H Bergstrand, "Economic Determinants of Free Trade Agreements," Journal of International Economics, 2004, 64 (1), 29-64.

Balassa, Bela, "Towards a Theory of Economic Integration," Kyklos, 1961, 16, 1-17.

Barbieri, Katherine, The liberal illusion: does trade promotes peace?, Ann Arbor: University of michigan Press, 2002.

Bearce, David H, "Grasping the Commercial Institutional Peace," International Studies Quarterly, 2003, $47(3), 347-370$.

- and Sawa Omori, "How do Commercial Insttitutions Promote Peace?," Journal of Peace Research, 2005, 42 (6), 659-678.

Bernheim, B D, B Peleg, and Whinston M D, "Coalition-proof Nash equilibri: Concepts," Journal of Economic Theory, 1987, 42 (1), 1-12.

Best, Edward, "Surpranational institutions and regional integration," 2005. Mimeo,.

Boehmer, Charles, Gartzke Erik A, and Quan Li, "Investing in the Peace: Economic Interdependence and International Conflict," International Organization, 2001, 55 (2), 391-438.

Bolton, Patrick, Grard Roland, and Enrico Spolaore, "Economic Theories of the Break-up and Integration of Nations," European Economic Review, 1996, 40 (3), 697-705.

Bouzas, Roberto and Hernan Soltz, "Institutions and Regional Integration: the Case of Mercosur," 2000. Mimeo (http://www.netamericas.net/Researchpapers/Documents/Bouzas/ Bouzas1.pdf).

Bremer, Jones Daniel M, Stuart A., and J. David Singer, "Militarized Interstate Disputes, 1816-1992: Rationale, Coding Rules, and Empirical Patterns," Conflict Management and Peace Science, 1996, 15 (2), 163-213.

Collier, Paul and Anke Hoeffler, "Unintended Consequences: Does Aid Promote Arms Races?," 2005. Mimeo.

Ethier, Wilfried, "The New Regionalism," The Economic Journal, 1998, 108, 1149-1161. 
Fearon, James D, "Rationalist Explanations for War," International Organization, 1995, 49 (3), $379-414$.

Foroutan, Faezeh, "Regional Integration in Sub-Saharan Africa: Past Experience and Future Prospects," in Jaime de Melo and Arvind Panagariya, eds., New Dimensions in Regional Integration, 1993.

_ , "Does Membership in an FTA make a country more or less protectionist?," The World Economy, 1998, 21 (3), 305-335.

Frankel, Jeffrey A, Regional Trading Blocs, Institute for International Economics, Washington, 1997.

_ , Ernesto Stein, and Shang-Jin Wei, "Regional Trading Arrangements: Natural or Supernatural?," American Economic Review, 1996, 86 (2), 52-56.

Ghosh, Sucharita and Steven Yamarik, "Are regional trading arrangements trade creating? An application of extreme bounds analysis," Journal of International Economics, 2004, 63 (2), 369-395.

_ and _, "Does trade creation mesure up? A reexamination of the effects of regional trading arrangements," Economics Letters, 2004, 82, 213-219.

Glick, Reuven and Alan M Taylor, "Collateral Damage: Trade Disruption and the Economic Impact of War," 2005. NBER Working Paper 11565.

Goldstein, Joshua S, "A Conflict-Cooperation Scale for WEIS International Events Data," Journal of Conflict Resolution, 1992, 36 (june), 369-385.

Greene, William, Econometric Analysis, New York: Prentice Hall, 2003.

Grieco, Joseph M, Cooperation Among Nations, Ithaca, NY and London: Cornell University Press, 1990.

Grossman, Herschel, "Choosing between Peace and War," 2004. The Timbergen Lecture Series, n.19, University of Saskatchewan.

Gwartney, James and Robert Lawson, Economic Freedom of the World: 2005 Annual Report, Vancouver: The Fraser Institute, 2005.

Haftel, Yoram Z, "Designing for Peace: Regional Integration Arrangements, Institutional Variation, and Militarized Inter-state Disputes," International Organization, Forthcoming.

Hirschleifer, Jack, "The Analytics of Continuing Conflicts," Synthese, 1988, 76, 201-233.

Kinsella, David and Bruce Russett, "Conflict Emergence and Escalation int Interactive International Dyads," The Journal of Politics, 2002, 64 (4), 1045-1068.

Langhammer, Rolf $\mathbf{J}$ and Ulrich Hiemenz, Regional integration among developing countries, Westview Press: JCB Mohr, 1990.

Machlup, F, A History of thought on economic integration, London: Macmillan, Chap.5, 1977.

Mansfield, Edward D and Brian M Pollins, "Interdependence and conflict: a conceptual and empirical overview," in Edward D Mansfield and Brian M Pollins, eds., Economic independence and international trade: new perspectives on an enduring debate, 2004. 
Mansfield, Edward D., Helen V. Milner, and B. Peter Rosendorff, "Why Democracies Cooperate More: Electoral Control and International Trade Agreements," International Organization, $2002,56(3), 477-513$.

Martin, Philippe, Thierry Mayer, and Mathias Thoenig, "Make Trade not War?," 2005. CEPR Discussion Paper N5218.

North, Douglas, Institutions, Institutional Change and Economic Performance, Cambridge MA: Cambridge University Press, 1990.

Pomfret, Richard, The Economics of Regional Trading Arrangements, Oxford University Press, 1997.

Reed, William, "A Unified Statistical Model of Conflict Onset and Escalation," American Journal of Political Science, 2000, 44 (1), 84-93.

Rodrik, Dani, "How Far Will International Economic Integration Go?," Journal of Economic Perspectives, 2000, 14 (1), 177-186.

Ruta, Michele, "Economic Theories of Political (Dis)integration," Journal of Economic Surveys, 2005, 19 (1), 1-21.

Schiff, Maurice, "Multilateral Trade Liberalization, Political Disintegration, and the choice of FTAs versus Customs Unions," 2004. UNU-CRIS e-Working Papers, W-2004/4.

_ and Alan L Winters, "Regional Integration as Diplomacy," 1997. World Bank Policy Research working Papers 1801.

Schrodt, Philip A and Deborah J Gerner, "Analyzing International Events Data: a Handbook of Computer-Based Techniques," 2000. University of Kansas, On-line Manuscript, http://www .ku . edu/ keds/papers.dir/automated.html.

Skaperdas, Stergios, "Cooperation, Conflict, and Power in the Absence of Property Rights," American Economic Review, 1992, 82 (4), 720-739.

Spolaore, Enrico, "Economic Integration, International Conflict and Political Union," Rivista di Politica Economica, 2004, September-October.

World Bank, Trade Blocs, Policy Research Report, Washington DC, 2000.

_, Global Economic Prospects 2005: Trade, Regionalism and Development, World Bank, Washington DC, 2005.

_, World Development Indicators, World Bank, Washington DC, Various issues. 


\title{
CESifo Working Paper Series
}

\author{
(for full list see www.cesifo-group.de)
}

1776 Richard Schmidtke, Two-Sided Markets with Pecuniary and Participation Externalities, August 2006

1777 Ben J. Heijdra and Jenny E. Ligthart, The Transitional Dynamics of Fiscal Policy in Small Open Economies, August 2006

1778 Jay Pil Choi, How Reasonable is the 'Reasonable' Royalty Rate? Damage Rules and Probabilistic Intellectual Property Rights, August 2006

1779 Ludger Woessmann, Efficiency and Equity of European Education and Training Policies, August 2006

1780 Gregory Ponthiere, Growth, Longevity and Public Policy, August 2006

1781 Laszlo Goerke, Corporate and Personal Income Tax Declarations, August 2006

1782 Florian Englmaier, Pablo Guillén, Loreto Llorente, Sander Onderstal and Rupert Sausgruber, The Chopstick Auction: A Study of the Exposure Problem in Multi-Unit Auctions, August 2006

1783 Adam S. Posen and Daniel Popov Gould, Has EMU had any Impact on the Degree of Wage Restraint?, August 2006

1784 Paolo M. Panteghini, A Simple Explanation for the Unfavorable Tax Treatment of Investment Costs, August 2006

1785 Alan J. Auerbach, Why have Corporate Tax Revenues Declined? Another Look, August 2006

1786 Hideshi Itoh and Hodaka Morita, Formal Contracts, Relational Contracts, and the Holdup Problem, August 2006

1787 Rafael Lalive and Alejandra Cattaneo, Social Interactions and Schooling Decisions, August 2006

1788 George Kapetanios, M. Hashem Pesaran and Takashi Yamagata, Panels with Nonstationary Multifactor Error Structures, August 2006

1789 Torben M. Andersen, Increasing Longevity and Social Security Reforms, August 2006

1790 John Whalley, Recent Regional Agreements: Why so many, why so much Variance in Form, why Coming so fast, and where are they Headed?, August 2006

1791 Sebastian G. Kessing and Kai A. Konrad, Time Consistency and Bureaucratic Budget Competition, August 2006 
1792 Bertil Holmlund, Qian Liu and Oskar Nordström Skans, Mind the Gap? Estimating the Effects of Postponing Higher Education, August 2006

1793 Peter Birch Sørensen, Can Capital Income Taxes Survive? And Should They?, August 2006

1794 Michael Kosfeld, Akira Okada and Arno Riedl, Institution Formation in Public Goods Games, September 2006

1795 Marcel Gérard, Reforming the Taxation of Multijurisdictional Enterprises in Europe, a Tentative Appraisal, September 2006

1796 Louis Eeckhoudt, Béatrice Rey and Harris Schlesinger, A Good Sign for Multivariate Risk Taking, September 2006

1797 Dominique M. Gross and Nicolas Schmitt, Why do Low- and High-Skill Workers Migrate? Flow Evidence from France, September 2006

1798 Dan Bernhardt, Stefan Krasa and Mattias Polborn, Political Polarization and the Electoral Effects of Media Bias, September 2006

1799 Pierre Pestieau and Motohiro Sato, Estate Taxation with Both Accidental and Planned Bequests, September 2006

1800 Øystein Foros and Hans Jarle Kind, Do Slotting Allowances Harm Retail Competition?, September 2006

1801 Tobias Lindhe and Jan Södersten, The Equity Trap, the Cost of Capital and the Firm's Growth Path, September 2006

1802 Wolfgang Buchholz, Richard Cornes and Wolfgang Peters, Existence, Uniqueness and Some Comparative Statics for Ratio- and Lindahl Equilibria: New Wine in Old Bottles, September 2006

1803 Jan Schnellenbach, Lars P. Feld and Christoph Schaltegger, The Impact of Referendums on the Centralisation of Public Goods Provision: A Political Economy Approach, September 2006

1804 David-Jan Jansen and Jakob de Haan, Does ECB Communication Help in Predicting its Interest Rate Decisions?, September 2006

1805 Jerome L. Stein, United States Current Account Deficits: A Stochastic Optimal Control Analysis, September 2006

1806 Friedrich Schneider, Shadow Economies and Corruption all over the World: What do we really Know?, September 2006

1807 Joerg Lingens and Klaus Waelde, Pareto-Improving Unemployment Policies, September 2006 
1808 Axel Dreher, Jan-Egbert Sturm and James Raymond Vreeland, Does Membership on the UN Security Council Influence IMF Decisions? Evidence from Panel Data, September 2006

1809 Prabir De, Regional Trade in Northeast Asia: Why do Trade Costs Matter?, September 2006

1810 Antonis Adam and Thomas Moutos, A Politico-Economic Analysis of Minimum Wages and Wage Subsidies, September 2006

1811 Guglielmo Maria Caporale and Christoph Hanck, Cointegration Tests of PPP: Do they also Exhibit Erratic Behaviour?, September 2006

1812 Robert S. Chirinko and Hisham Foad, Noise vs. News in Equity Returns, September 2006

1813 Oliver Huelsewig, Eric Mayer and Timo Wollmershaeuser, Bank Behavior and the Cost Channel of Monetary Transmission, September 2006

1814 Michael S. Michael, Are Migration Policies that Induce Skilled (Unskilled) Migration Beneficial (Harmful) for the Host Country?, September 2006

1815 Eytan Sheshinski, Optimum Commodity Taxation in Pooling Equilibria, October 2006

1816 Gottfried Haber and Reinhard Neck, Sustainability of Austrian Public Debt: A Political Economy Perspective, October 2006

1817 Thiess Buettner, Michael Overesch, Ulrich Schreiber and Georg Wamser, The Impact of Thin-Capitalization Rules on Multinationals' Financing and Investment Decisions, October 2006

1818 Eric O’N. Fisher and Sharon L. May, Relativity in Trade Theory: Towards a Solution to the Mystery of Missing Trade, October 2006

1819 Junichi Minagawa and Thorsten Upmann, Labor Supply and the Demand for Child Care: An Intertemporal Approach, October 2006

1820 Jan K. Brueckner and Raquel Girvin, Airport Noise Regulation, Airline Service Quality, and Social Welfare, October 2006

1821 Sijbren Cnossen, Alcohol Taxation and Regulation in the European Union, October 2006

1822 Frederick van der Ploeg, Sustainable Social Spending in a Greying Economy with Stagnant Public Services: Baumol’s Cost Disease Revisited, October 2006

1823 Steven Brakman, Harry Garretsen and Charles van Marrewijk, Cross-Border Mergers \& Acquisitions: The Facts as a Guide for International Economics, October 2006 
1824 J. Atsu Amegashie, A Psychological Game with Interdependent Preference Types, October 2006

1825 Kurt R. Brekke, Ingrid Koenigbauer and Odd Rune Straume, Reference Pricing of Pharmaceuticals, October 2006

1826 Sean Holly, M. Hashem Pesaran and Takashi Yamagata, A Spatio-Temporal Model of House Prices in the US, October 2006

1827 Margarita Katsimi and Thomas Moutos, Inequality and the US Import Demand Function, October 2006

1828 Eytan Sheshinski, Longevity and Aggregate Savings, October 2006

1829 Momi Dahan and Udi Nisan, Low Take-up Rates: The Role of Information, October 2006

1830 Dieter Urban, Multilateral Investment Agreement in a Political Equilibrium, October 2006

1831 Jan Bouckaert and Hans Degryse, Opt In Versus Opt Out: A Free-Entry Analysis of Privacy Policies, October 2006

1832 Wolfram F. Richter, Taxing Human Capital Efficiently: The Double Dividend of Taxing Non-qualified Labour more Heavily than Qualified Labour, October 2006

1833 Alberto Chong and Mark Gradstein, Who's Afraid of Foreign Aid? The Donors' Perspective, October 2006

1834 Dirk Schindler, Optimal Income Taxation with a Risky Asset - The Triple Income Tax, October 2006

1835 Andy Snell and Jonathan P. Thomas, Labour Contracts, Equal Treatment and WageUnemployment Dynamics, October 2006

1836 Peter Backé and Cezary Wójcik, Catching-up and Credit Booms in Central and Eastern European EU Member States and Acceding Countries: An Interpretation within the New Neoclassical Synthesis Framework, October 2006

1837 Lars P. Feld, Justina A.V. Fischer and Gebhard Kirchgaessner, The Effect of Direct Democracy on Income Redistribution: Evidence for Switzerland, October 2006

1838 Michael Rauscher, Voluntary Emission Reductions, Social Rewards, and Environmental Policy, November 2006

1839 Vincent Vicard, Trade, Conflicts, and Political Integration: the Regional Interplays, November 2006 